\title{
TO ARREST OR NOT TO ARREST THE INCUMBENT HEAD OF STATE: THE BASHIR CASE AND THE INTERPLAY BETWEEN LAW AND POLITICS
}

\author{
JADRANKA PETROVIC, ${ }^{*}$ DALE STEPHENS, ${ }^{* *}$ VASKO NASTEVSKI ${ }^{\star * *}$
}

\begin{abstract}
In 2009, Sudanese President Omar Hassan Ahmad Al Bashir ('President Bashir') was indicted by the International Criminal Court ('ICC') on charges of war crimes and crimes against humanity over the conflict in the western region of Darfur, Sudan. The following year the ICC charged President Bashir with genocide over events in Darfur, where allegedly more than 300000 people have died and more than two million people have been displaced since 2003. Before the ICC can prosecute President Bashir, it has to obtain custody over him. As a judicial institution without power to arrest those it indicts, the Court relies on national authorities. States to which President Bashir has travelled since the warrants for his arrest have been issued have been reluctant to arrest and surrender President Bashir to the ICC justifying their refusal by the head of state immunity argument. By focusing on the specific response of the South African government to the ICC's arrest warrant against President Bashir in June 2015, this article considers the question of whether states must cooperate with the ICC in instances of an arrest warrant against a sitting head of state of a non-state party and observes the broader implications of state responses similar to the South African case.
\end{abstract}

\section{INTRODUCTION}

If Bashir were to come to South Africa today, we will definitely implement what we are supposed to in order to bring the culprit to [The] Hague. ... We can't allow

* Dr Jadranka Petrovic (SJD, LLM, LLB, PGradDiplIntLaw, PgradCertAustrLaw (Melb), GCAP (Monash)) currently teaches and researches at Monash University, Melbourne, Australia.

** Professor Dale Stephens currently teaches and researches at the University of Adelaide Law School, Australia.

*** Dr Vasko Nastevski (PhD, MPubIntLaw, BA) currently works at the Department of Treasury and Finance, State Government Victoria, Australia.

The authors are indebted to anonymous reviewers for their invaluable constructive feedback. The authors would also like to thank their colleague, who for personal reasons prefers to stay anonymous, for their input relating to some sections of the initial draft of this article, and to Mr Benjamin Grunberg and Mr Mark Giddings for their research assistance also relating to some sections of the first draft of this article. The authors' special thanks to the wonderful Monash University Law Review Editors for their helpful suggestions and outstanding editing of this article. 
a situation whereby an individual tramples on people's rights and gets away with it ... The perpetrators of war crimes should be tried at all costs. ${ }^{1}$

The deputy secretary of the ruling African National Congress Party in South Africa, Thandi Modise, could not have been any clearer in articulating the position of South Africa in relation to the indictment of Omar Hassan Ahmad Al Bashir, President of the Republic of the Sudan ('President Bashir') by the International Criminal Court ('ICC'). However, at the $25^{\text {th }}$ Ordinary Summit of the African Union ('AU Summit') held in South Africa during June 2015, despite being a State Party to the Rome Statute of the International Criminal Court ('ICC Statute'), ${ }^{2}$ South Africa failed to act on two outstanding arrest warrants issued by the ICC against President Bashir on 4 March 2009 and on 12 July 2010 respectively. ${ }^{3}$ Moreover, President Bashir was allowed to leave the country in defiance of a decision issued by the High Court of South Africa, which stated that:

the [South African authorities] are forthwith compelled to take all reasonable steps to prepare to arrest President Bashir ... and detain him, pending a formal request for his surrender from the International Criminal Court. ${ }^{4}$

President Bashir's exit from South Africa has been widely regarded as occurring 'with the complicity of his hosts'. judgment of 24 June 2015, noted that President Bashir's departure occurred 'in the full awareness of the explicit order' by the South African High Court, which clearly demonstrated 'non-compliance with that order' and that consideration be given whether 'criminal proceedings are appropriate'. ${ }^{6}$ There is a clear disconnect between the South African judiciary's express requirement for South Africa to abide by its legal obligations to cooperate with the ICC 'to effect the arrest ... of persons suspected of war crimes, genocide and crimes against humanity', ${ }^{7}$ and

1 Thandi Modise, quoted in 'South Africa Says It Will Arrest Sudan's Bashir Despite AU Resolution', Sudan Tribune (online), 31 July $2010<\mathrm{http}: / /$ www.sudantribune.com/spip.php?article35817>.

2 Rome Statute of the International Criminal Court, opened for signature 17 July 1998, 2187 UNTS 90 (entered into force 1 July 2002) ('ICC Statute'). For a status of States Parties to the ICC Statute see Rome Statute of the International Criminal Court, United Nations Treaty Collection $<\mathrm{https} / /$ treaties.un.org/Pages/ViewDetails.aspx?src=TREATY\&mtdsg_no=XVIII-10\&chapter=18\&clang $=$ en>. South Africa signed the ICC Statute on 17 July 1998 and on 27 November 2000 it deposited its instrument of ratification. To domesticate the obligations in the ICC Statute, South Africa's parliament drafted the Implementation of the Rome Statute of the International Criminal Court Act 2002 (South Africa) ('Implementation Act'), which became law on 16 August 2002.

3 Prosecutor v Al Bashir (Warrant of Arrest) (International Criminal Court, Pre-Trial Chamber I, Case No ICC-02/05-01/09, 4 March 2009) ('First Arrest Warrant'); Prosecutor v Al Bashir (Second Warrant of Arrest) (International Criminal Court, Pre-Trial Chamber I, Case No ICC-02/05-01/09-1, 12 July 2010) ('Second Arrest Warrant').

4 Southern Africa Litigation Centre v Minister of Justice and Constitutional Development [2015] 5 SA 1, 3 [2] (High Court) ('Southern Africa Litigation Centre').

5 David E Kiwuwa, 'Al-Bashir: South Africa's Moment of Glory and Shame', The Conversation (online), 19 June $2015<\mathrm{http}$ ///theconversation.com/al-bashir-south-africas-moment-of-glory-andshame-43283>.

6 Southern Africa Litigation Centre [2015] 5 SA 1, 30 [39] (High Court). This judgment concerned a consideration of the duties and obligations of South Africa in the context of the Implementation Act, precisely, the question of "whether a Cabinet Resolution coupled with a Ministerial Notice are capable of suspending [South Africa's] duty to arrest a head of state against whom the [ICC] has issued arrest warrants for war crimes, crimes against humanity and genocide': at 3 [1]. 
the lack of political will on behalf of the South African authorities to fulfil these obligations.

However, this was not the first occasion in which an African state failed to act on the outstanding ICC arrest warrants against President Bashir and seems to reflect a general 'African disengagement" from the work of the ICC (including the AU's stance vis-à-vis ICC involvements regarding other African leaders, such as Kenyatta and Gaddafi). The AU has frequently expressed solidarity with President Bashir and has issued decisions in which they state that AU members 'shall not cooperate' with the ICC relating to immunities for the 'arrest and surrender of President [Omar Al Bashir] of The Sudan'.9 This general disposition at discrediting the $\mathrm{ICC}^{10}$ as well as the recent failings by South Africa, has implications for the future effectiveness of the ICC. As this article highlights, clear challenges lie ahead for the international community to ensure that the road to international criminal justice remains steadfast.

One of the defining characteristics of Prosecutor v Omar Hassan Ahmad Al Bashir $^{11}$ is the fact that the Sudanese President is the first sitting head of state of a non-party to the ICC Statute to face the prospect of being prosecuted for the commission of international crimes by the ICC. ${ }^{12}$ This article explores the questions of whether an incumbent head of state can be prosecuted and whether States Parties to the ICC Statute have a duty to arrest a head of state, which

8 E Van Trigt, Africa and Withdrawal from the ICC (28 October 2016) Peace Palace Library $<$ https://www.peacepalacelibrary.nl/2016/10/africa-and-icc-withdrawal/>. The position of South Africa and also of the AU is further contextualised by ICC involvements regarding other African leaders, eg, Kenyatta and Gaddafi (although these involvements are different in some respects). Kenyan President Uhuru Kenyatta, who was charged with crimes against humanity for his alleged role in post-election violence, was the first sitting head of state to appear before the ICC in 2013. However, the ICC Prosecutor withdrew charges due to insufficient evidence. In January 2016, supporting South Africa's stance vis-à-vis President Bashir, President Kenyatta pleaded with the AU for a 'roadmap for withdrawal' for 34 African states from the ICC Statute. President Kenyatta pinpointed art 27 of the ICC Statute, which affirms the 'irrelevance of official capacity' for crimes within the purview of the ICC Statute, and then (given the 2017 election) played the global security card implying that this 'compromised' Kenya's ability to fight Islamist militancy: see, eg, International Criminal Court, Situations Under Investigation <https:/www.icc-pi.int/pages/situations.aspx>; Ed Cropley, 'ICC's Toughest Trial: Africa vs. "Infamous Caucasian Court"” Reuters Africa (online), 28 October 2016 $<$ http://af.reuters.com/article/topNews/idAFKCN12S1MQ?sp=true>. Similarly, following the 15 February 2011 demonstrations against the Gaddafi administration in Libya and the UN Security Council's referral of the situation to the ICC, which resulted in, inter alia, a warrant of arrest against the then Head of State Muammar Gaddafi, the AU raised its concerns noting that this arrest warrant undermined its efforts in facilitating peaceful solution. As with the Bashir case, the AU decided not to cooperate with the ICC: see, eg, Juliet Okoth, 'Africa, the United Nations Security Council and the International Criminal Court: The Question of Deferrals' in Gerhard Werle, Lovell Fernandez and Moritz Vormbaum (eds), Africa and the International Criminal Court (Springer, 2014) 197.

9 African Union Assembly, Decision on the Meeting of African States Parties to the Rome Statute of the International Criminal Court, Assembly/AU/Dec.245 (XIII) (3 July 2009) [10] ('2009 AU Decision').

10 Kai Ambos, "Expanding the Focus of the "African Criminal Court"' in William A Schabas, Yvonne McDermott and Niamh Hayes (eds), The Ashgate Research Companion to International Criminal Law: Critical Perspectives (Ashgate, 2013) 499.

11 (International Criminal Court, Pre-Trial Chamber I, Case No ICC-02/05-01/09) ('Bashir').

12 For a comment on the case of Prosecutor v Slobodan Milošević (Decision on Preliminary Motions) (International Criminal Tribunal for the former Yugoslavia, Case No IT-02-54, 8 November 2001), see below n 168 . 
remain open amongst some international legal scholars who argue that this would be breaching the personal immunity granted to heads of state under rules of customary international law. ${ }^{13}$ However, in view of the Bashir case, by issuing the warrants of arrest the ICC found that President Bashir does not enjoy immunity from prosecution as it would be inconsistent with the purposes and framework of the ICC Statute; that President Bashir's official capacity as head of state provides no exemption from criminal responsibility and that there are no exceptions in this case; and that the UN Security Council removed any personal immunities by referring the situation in Darfur to the ICC. ${ }^{14}$ The Bashir case potentially represents a benchmark for international criminal justice to the extent that it enhances the legal pedigree providing for the prosecution of serving heads of state of non-parties to the ICC Statute..$^{15}$

This article argues that South Africa had clear legal obligations to arrest President Bashir. The article articulates these obligations, which begin with South Africa's duty to comply with the provisions of the ICC Statute. The existence of the charge of genocide against President Bashir further obligated South Africa to act. The legal obligation to prevent and punish the crime of genocide was initially set out in the Convention on the Prevention and Punishment of the Crime of Genocide, ${ }^{16}$ but has since emerged as a binding rule of customary international law and represents both erga omnes and jus cogens obligation. ${ }^{17}$ South Africa's obligation to arrest President Bashir was reinforced by Sudan's and South Africa's UN membership. ${ }^{18}$ As this article observes, there are potential consequences that flow from South Africa's failure to fulfil this duty. These include the ICC finding South Africa in breach of its obligations under the ICC Statute and resulting in a referral to the Assembly of States Parties to the ICC and even to the Security Council for possible action. In the meantime, on the ICC's website, the words 'at large' continue to be displayed next to the Bashir case somewhat uncomfortably. ${ }^{19}$

By focusing on the South African example, this article provides a comprehensive assessment of some states' failure to act upon the ICC's arrest warrants for President Bashir. The article comprises six parts. Part I provides a general introduction. Part II overviews the Bashir case with the aim to provide context for the discussion in the following parts and simultaneously to demonstrate the seriousness of the

13 See discussion in pt $\mathrm{V}$ B-C below.

14 Prosecutor v Al Bashir (Decision on the Prosecution's Application for a Warrant of Arrest against Omar Hassan Ahmad Al Bashir) (International Criminal Court, Pre-Trial Chamber I, Case No ICC02/05-01/09, 4 March 2009) [42]-[45] ('Decision on the Prosecution's Application for a Warrant of Arrest').

15 Penrose argues such 'legal pedigree' does not currently exist: see Mary M Penrose, 'The Emperor's Clothes: Evaluating Head of State Immunity under International Law’ (2010) 7 Santa Clara Journal of International Law 85, 88.

16 Convention on the Prevention and Punishment of the Crime of Genocide, opened for signature 9 December 1948, 78 UNTS 1021 (entered into force 12 January 1951) ('Genocide Convention').

17 See generally M Cherif Bassiouni, 'International Crimes: Jus Cogens and Obligatio Erga Omnes' (1996) 59(4) Law and Contemporary Problems 63.

18 See discussion in pt $\mathrm{V}$ below.

19 See International Criminal Court, Darfur, Sudan: Situation in Darfur, Sudan <http://www.icccpi.int/en_menus/icc/situations\%20and\%20 cases/situations/situation\%20icc\%200205/Pages/ situation\%20icc-0205.aspx>. 
crimes with which President Bashir is charged and the associated importance of his arrest. Part III looks at South Africa's response to the obligation to cooperate with the ICC and arrest President Bashir. This part surveys steps taken by both the South African Government and South African judiciary vis-à-vis President Bashir's visit to South Africa in June 2015, highlighting the divergence between the law and politics in the African milieu. Part IV outlines the law concerning head of state immunity. Part V considers pro et contra arguments relating to the specific June 2015 events in South Africa and observes the broader consequences created by those events. Part VI concludes that despite a legal basis for arrest of President Bashir, political nuances of the case curtailed President Bashir's arrest creating implications for future effectiveness of the ICC.

\section{THE BASHIR CASE}

\section{A Understanding the Sudanese Situation}

During the course of 2004, Western media began to increasingly raise awareness of the situation taking place in Sudan. Pronouncements were made about 'the worst humanitarian crisis in the world' ${ }^{20}$ and more than one million people 'being affected by ethnic cleansing,. ${ }^{21}$ In the United States, the then Secretary of State, Colin Powell, testified before the US Senate Foreign Relations Committee where he stated that 'genocide has been committed in Darfur and that the Government of Sudan and the Jingaweit bear responsibility — and that genocide may still be occurring, ${ }^{22}$

On 18 September 2004, acting under ch VII of the Charter of the United Nations, the UN Security Council adopted a resolution in which they requested that:

the Secretary-General rapidly establish an international commission of inquiry in order immediately to investigate reports of violations of international humanitarian law and human rights law in Darfur by all parties, to determine also whether or not acts of genocide have occurred, and to identify the perpetrators of such violations with a view to ensuring that those responsible are held accountable.$^{23}$

\section{B Crimes Committed in Darfur}

The findings of the subsequent International Commission of Inquiry on Darfur ('Darfur Commission') regarding the types of violations committed were elaborate

20 Ed O'Keefe and Jeffrey Marcus, 'Crisis in Sudan', The Washington Post (online), 9 September 2004 $<$ http://www.washingtonpost.com/wp-dyn/articles/A20765-2004Jul1.html>.

21 'Mass Rape Atrocity in West Sudan', BBC News (online), 19 March $2004<\mathrm{http}$ ://news.bbc.co.uk/2/ hi/africa/3549325.stm>.

22 Colin L Powell, The Crisis in Darfur (9 September 2004) US Department of State Archive $<$ http://2001-2009.state.gov/secretary/former/powell/remarks/36042.htm>.

23 SC Res 1564, UN SCOR, 59 $9^{\text {th }}$ sess, 5040 ${ }^{\text {th }} \mathrm{mtg}$, UN Doc S/RES/1564 (18 September 2004) para 12. 
and included numerous individual case studies. ${ }^{24}$ In the Commission's view, these violations amounted to war crimes and crimes against humanity. ${ }^{25}$

The Darfur Commission Report did also make findings in relation to whether acts of genocide occurred. To this extent, the Darfur Commission concluded that the government of Sudan did not pursue a policy of genocide as the crucial element of 'genocidal intent' did not appear to be present. ${ }^{26}$ However, the Darfur Commission Report did go on to qualify this decision in the following manner:

The Commission does recognize that in some instances, individuals, including Government officials, may commit acts with genocidal intent. Whether this was the case in Darfur, however, is a determination that only a competent court can make on a case-by-case basis. ${ }^{27}$

Luban draws a direct corollary in the evidence between the situation in Darfur and the events that took place in Srebrenica, but highlights how the Darfur Commission and the International Criminal Tribunal for the Former Yugoslavia ('ICTY') reach totally different legal conclusions. ${ }^{28}$

Nevertheless, the Darfur Commission recommended that 'the Security Council ... refer the situation in Darfur to the International Criminal Court', as many of the alleged crimes met 'all the thresholds' of the Court and Sudan had 'demonstrated its inability and unwillingness to investigate and prosecute the perpetrators' ${ }^{29}$ The Darfur Commission did not identify the alleged perpetrators specifically, but noted that they consisted of individuals that included 'officials of the Government of the Sudan'. ${ }^{30}$ It was recommended that a sealed file with all of the names of the perpetrators be handed to the ICC. ${ }^{31}$

\section{President Bashir's Role}

On 31 March 2005, acting under ch VII of the Charter of the United Nations, the Security Council did in fact, by Resolution 1593, refer the situation in Darfur to the Prosecutor of the ICC. ${ }^{32}$ The number of votes in favour of Resolution 1593 was

24 Darfur Commission, Report of the International Commission of Inquiry on Darfur to the United Nations Secretary-General (25 January 2005) <http://www.un.org/news/dh/sudan/com_inq_darfur. pdf> ('Darfur Commission Report').

25 Ibid 73 [267]-[268].

26 Ibid 160 [640].

27 Ibid 161 [641] (emphasis added). The Darfur Commission emphasised the possible existence of other 'indicative elements' that could be construed as demonstrating a lack of genocidal intent. One example given was that attacking villages may have been in pursuit of an intention to drive the victims from their homes primarily for 'counter-insurgency purposes': at 130-2.

28 David Luban, 'Calling Genocide by Its Rightful Name: Lemkin's Word, Darfur, and the UN Report' (2006) 7(1) Chicago Journal of International Law 303, 314.

29 Darfur Commission Report, above n 24, 162 [647].

30 Ibid 161 [644].

31 Ibid 161-2 [644]-[645].

32 SC Res 1593, UN SCOR, 60 ${ }^{\text {th }}$ sess, $5158^{\text {th }} \mathrm{mtg}$, UN Doc S/RES/1593 (31 March 2005) ('Resolution $\left.1593^{\prime}\right)$. 
11, none against, with four abstentions. ${ }^{33}$ One of the abstentions came from the US, although in explaining their position the US representative expressed support for bringing to justice those responsible for the crimes and noted that 'by adopting [the] resolution, the international community had established an accountability mechanism for the perpetrators of crimes and atrocities in Darfur' ${ }^{34}$

The ICC is able to exercise its jurisdiction over the alleged crimes pursuant to art 13(b) of its Statute, which provides for such jurisdiction in 'a situation in which one or more of such crimes appears to have been committed is referred to the Prosecutor by the Security Council acting under ch VII of the Charter of the United Nations'. ${ }^{35}$

The rationale of art 13(b) is to empower the ICC to prosecute crimes committed in the territory of a State Party non-party to the ICC Statute by individuals who are not nationals a State Party, ${ }^{36}$ which is the case in the Sudan. This supplements the provisions of art 12(2) of the ICC Statute which provide that for matters referred to the ICC by a State Party or where the ICC prosecutor has initiated an investigation proprio motu, the ICC will only exercise its jurisdiction where the 'conduct in question occurred' in the territory of a State Party or the 'the person accused of the crime is a national' of a State Party. ${ }^{37}$

Following an investigation by the ICC, Pre-Trial Chamber I found that there were reasonable grounds to believe that 'Omar Al Bashir is criminally responsible under article 25(3)(a) of the [ICC] Statute as an indirect perpetrator, or as an indirect co-perpetrator for those war crimes and crimes against humanity' found by the Chamber to have occurred in Darfur. ${ }^{38}$ Article 25(3)(a) of the ICC Statute provides that:

a person shall be criminally responsible and liable for punishment for a crime within the jurisdiction of the Court if that person:

(a) Commits such a crime, whether as an individual, jointly with another or through another person, regardless of whether that other person is criminally responsible. ${ }^{39}$

Accordingly, Pre-Trial Chamber I held that art 25(3)(a) of the ICC Statute embraces 'four manifestations of the notion of control of the crime', including direct perpetration, indirect perpetration, co-perpetration and indirect co-

The following states abstained: Algeria, Brazil, China and the US. Criminal Court' (Press Release, SC/8351, 31 March 2015) <http://www.un.org/press/en/2005/sc8351. doc.htm>. The US' abstention might be due to their own reticence to join the ICC Statute and the issue of non-state parties being bound by the Statute.

36 Dapo Akande, 'The Effect of Security Council Resolutions and Domestic Proceedings on State Obligations to Cooperate with the ICC' (2012) 10 Journal of International Criminal Justice 299, 301.

37 ICC Statute art 12(2).

38 Decision on the Prosecution's Application for a Warrant of Arrest (International Criminal Court, Pre-Trial Chamber I, Case No ICC-02/05-01/09, 4 March 2009) [223]. 
perpetration'. ${ }^{40}$ In this light, Pre-Trial Chamber I found that President Bashir, together with other high ranking Sudanese political and military leaders, agreed on 'a common plan to carry out a counter-insurgency campaign against the SLM/A [and JEM]'; ${ }^{\prime 4}$ that this common plan included unlawful attacks on certain elements of the civilian population in Darfur; ${ }^{42}$ that these unlawful attacks involved 'forcible transfers and acts of murder, extermination, rape, torture, and pillage';3 that President Bashir and the other high ranking Sudanese officials "directed the branches of the "apparatus" of the State of Sudan ... in a coordinated manner, in order to jointly implement the common plan'; ${ }^{\prime}$ that the common plan was to a large extent implemented through local Security Committees, which necessarily included the Janjaweed:45 and that Al Bashir as President of Sudan and Commander-in-Chief of the Sudanese Armed Forces played an essential role in 'coordinating the design and implementation of the common plan' ${ }^{46}$ In the alternative, Pre-Trial Chamber I also found reasonable grounds that President Bashir played a role that went beyond coordination, that he "was in full control of all branches of the "apparatus" of the State' and that he 'used such control to secure the implementation of the common plan'. ${ }^{47}$

Similar to the Darfur Commission's findings in respect to the crime of genocide, Pre-Trial Chamber I concluded that the existence of reasonable grounds to believe that the Government of Sudan acted with the necessary specific genocidal intent was not the only reasonable conclusion that could be drawn. Therefore, there was no recommendation for a warrant of arrest to be issued against President Bashir for the crime of genocide. ${ }^{48}$ The warrant of arrest issued against President Bashir on 4 March 2009 was confined to the various crimes relating to war crimes and crimes against humanity. These included intentionally directing attacks against a civilian population as such or against civilians not taking direct part in hostilities and pillage as war crimes, and murder, extermination, forcible transfer, torture and rape as crimes against humanity. ${ }^{49}$

Following an appeal by the Prosecutor of the ICC against the decision of PreTrial Chamber I, on 3 February 2010 the Appeals Chamber reversed the Pre-Trial Chamber's decision 'to the extent that Pre-Trial Chamber I decided not to issue a

49 Decision on the Prosecution's Application for a Warrant of Arrest (International Criminal Court, Pre-Trial Chamber I, Case No ICC-02/05-01/09, 4 March 2009) [38]-[39]. 
warrant of arrest in respect of the crime of genocide'. ${ }^{50}$ The reasoning behind the Appeals Chamber decision related to the evidentiary threshold necessary for the issuance of a warrant of arrest, which pursuant to art 58(1)(a) of the ICC Statute is 'reasonable grounds to believe that the person has committed a crime'. The Appeals Chamber distinguished this test with that of the threshold required to confirm charges, being 'substantial grounds to believe' and the threshold for a conviction, being 'beyond reasonable doubt' ${ }^{51}$ Both of these are higher evidentiary standards. In requiring the existence of genocidal intent as the only reasonable conclusion, the Appeals Chamber noted that Pre-Trial Chamber I placed a requirement on the Prosecutor to disprove any other reasonable conclusion, thereby having to eliminate any reasonable doubt. This was an 'erroneous standard' and one that 'was higher and more demanding than what is required under [art 58(1)(a)] of the Statute'. ${ }^{2}$

On 12 July 2010, Pre-Trial Chamber I issued a second decision on the Prosecutor's application for a warrant of arrest against President Bashir, in line with the Appeals Chamber conclusion, which is binding. ${ }^{53}$ A separate self-executing warrant of arrest was issued against President Bashir for the crime of genocide on the same day, which included genocide by killing, by causing serious bodily or mental harm and by deliberately inflicting conditions of life calculated to bring about physical destruction. ${ }^{54}$ The Darfur conflict remains the only application of the crime of genocide by the ICC and the only application of the crime of genocide by the ICC allegedly committed by an incumbent Head of State nonparty to the ICC Statute. ${ }^{55}$

\section{SOUTH AFRICA'S FAILURE TO ARREST PRESIDENT BASHIR}

\section{A Communications between the ICC and South Africa}

Since the two arrest warrants have been issued, President Bashir has travelled to other states on several occasions, including to Chad (21 July 2010 and 7 August 2011), Kenya (28 August 2010), Djibouti (8 May 2010), Malawi (1 December 2010), the Democratic Republic of the Congo (25 February 2014) and South

50 Prosecutor v Al Bashir (Judgment on the Appeal of the Prosecutor against the Decision on the Prosecution's Application for a Warrant of Arrest against Omar Hassan Ahmad Al Bashir) (International Criminal Court, Appeals Chamber, Case No ICC-02/05-01/09-OA, 3 February 2010) 3.

51 Ibid [30].

52 Ibid [34], [39].

53 Prosecutor v Al Bashir (Second Decision on the Prosecution's Application for a Warrant of Arrest), (International Criminal Court, Pre-Trial Chamber I, Case No ICC-02/05-01/09, 12 July 2010).

54 Second Arrest Warrant (International Criminal Court, Pre-Trial Chamber I, Case No ICC-02/0501/09, 12 July 2010) 8.

55 Marjolein Cupido, 'The Contextual Embedding of Genocide: A Casuistic Analysis of the Interplay Between Law and Facts' (2014) 15 Melbourne Journal of International Law 378, 401. 
Africa (13 June 2015). ${ }^{56}$ On each such occasion, the host states failed to arrest President Bashir. It is President Bashir's travel to South Africa that is of the most immediate concern here.

In order to prevent repetition of this approach to the ICC's arrest warrants, in the period leading up to President Bashir entering South Africa for the $25^{\text {th }} \mathrm{AU}$ Summit, taking place in Johannesburg in June 2015, several direct and indirect communications occurred between the ICC and South Africa concerning the status of arrest warrants for President Bashir and South Africa's international obligations in regards to these warrants. South Africa's international obligation, as a party to the ICC Statute, ${ }^{57}$ to execute ICC arrest warrants was first flagged by the ICC on 28 May 2015. The ICC communicated a note verbale to the embassy of South Africa in the Netherlands reminding it of 'South Africa's obligation to arrest Omar Al Bashir and surrender him to the Court, and, in case of any difficulties in implementing the request for cooperation, to consult with the Court without any delay in accordance with article 97 of the Statute, ${ }^{58}$ Subsequently, in the ICC 'Weekly Update \#248' of 16 June 2015, the President of the Assembly of States Parties to the ICC Statute, Sidiki Kaba, called on South Africa 'to spare no effort in ensuring the execution of the arrest warrants', and urged them 'to respect their obligations to cooperate with the Court', expressing his concern regarding 'the negative consequences for the Court in case of non-execution of the warrants by States Parties. ${ }^{59}$

\section{A Note Verbale of 12 June 2015}

On 12 June, Judge Cuno Tarfusser, Presiding Judge in the Bashir case, met with the Ambassador of South Africa to the Netherlands. A note verbale was read out by the Ambassador claiming that 'there was lack of clarity in the law and that the Republic of South Africa was subject to competing obligations' ${ }^{90}$ The 'competing obligations' to which the Ambassador referred involved, in South Africa's view,

56 See generally Gwen P Barnes, 'The International Criminal Court's Ineffective Enforcement Mechanisms: The Indictment of President Omar Al Bashir' (2011) 34 Fordham International Law Review 1584. President Bashir travelled to other states even after the failure of South Africa to arrest him, for example, on 7 March 2016 for the extraordinary Organisation of Islamic Cooperation ('OIC') summit on Palestinian issues in Jakarta, Indonesia. Although Indonesia is not a party to the ICC Statute, as a UN member Indonesia is under an obligation to comply with UN Security Council Resolution 1593 which referred the Darfur situation to the Office of the Prosecutor of the ICC and which urges all UN members to fully cooperate with the ICC: see Coalition for the International Criminal Court, States: Arrest ICC Fugitive Al-Bashir in Indonesia (7 March 2016) CIC Global Justice <https://ciccglobaljustice.wordpress.com/2016/03/07/states-arrest-icc-fugitive-al-bashir-inindonesia/>.

57 See generally ICC Statute pt IX arts 86-102 on international cooperation and judicial assistance.

58 Prosecutorv Al Bashir (Decision following the Prosecutor's Request for an Order Further Clarifying that the Republic of South Africa is under the Obligation to Immediately Arrest and Surrender Omar Al Bashir) (International Criminal Court, Pre-Trial Chamber II, Case No ICC-02/05-01/09, 13 June 2015) [3] ('PTC II Decision of 13 June 2015').

59 International Criminal Court, 'ICC Weekly Update \#248' (Media Release, 248/15, 13 June 2015) 1.

60 PTC II Decision of 13 June 2015 (International Criminal Court, Pre-Trial Chamber II, Case No ICC02/05-01/09, 13 June 2015) [4]. 
the duty of South Africa to act upon the arrest warrants and the duty of South Africa not to arrest President Bashir due to his immunity as a sitting head of state.

In response Judge Tarfusser explained to the Ambassador that 'there is no ambiguity in the law and that the Republic of South Africa is under the obligation to arrest and surrender to the Court Omar Al Bashir. ${ }^{61}$ Judge Tarfusser cited the Pre-Trial Chamber II Decision on the Cooperation of the Democratic Republic of the Congo regarding Omar Al Bashir's Arrest and Surrender to the Court, ${ }^{62}$ in which identical issues to those raised by South Africa were settled.

\title{
(a) The DRC Decision
}

In this case, the Democratic Republic of Congo ('DRC') argued that they were legally constrained from arresting President Bashir due to the AU's decision passed on 12 October 2013 that

\begin{abstract}
'[...] no serving AU Head of State or Government [...], shall be required to appear before any international court or tribunal during their term of office'. [As such, the ICC arrest warrant was] 'inconsistent with their obligation to respect the immunities' attached to his position as a Head of State. ${ }^{63}$
\end{abstract}

In response to this claim, the $D R C$ Decision states that '[a]n exception to the personal immunities of Heads of States is explicitly provided in article 27(2) of the Statute for prosecution before an international criminal jurisdiction'. ${ }^{64}$ Article 27(2) of the ICC Statute stipulates that '[i]mmunities or special procedural rules which may attach to the official capacity of a person, whether under national or international law, shall not bar the Court from exercising its jurisdiction over such a person'. As a result, 'the existence of personal immunities under international law which generally attach to the official capacity of the person "shall not bar the Court from exercising its jurisdiction over such a person"”. ${ }^{65}$

\section{(i) The Reach of Article 27}

As Sudan is not a party to the ICC Statute, however, the DRC Decision then goes on to examine the reach of art 27 and whether it applies to heads of state of third parties. It concludes that under the Vienna Convention on the Law of Treaties, ${ }^{6}{ }^{6}$ the ICC Statute cannot impose obligations on non-party states without their consent. As such the exception to head of state immunity contained in art 27(2)

61 Ibid [5].

62 Prosecutor $v$ Al Bashir (Decision on the Cooperation of the Democratic Republic of the Congo Regarding Omar Al Bashir's Arrest and Surrender to the Court) (International Criminal Court, PreTrial Chamber II, Case No ICC-02/05-01/09-1, 9 April 2014) ('DRC Decision'). Judge Tarfusser in particular referred to [28]-[31] of this decision.

63 Ibid [19].

64 Ibid [25].

65 Ibid.

66 Vienna Convention on the Law of Treaties, opened for signature 23 May 1969, 1155 UNTS 331 (entered into force 27 January 1980) art 34 ('Vienna Convention'). For exceptions to the rule, see arts 35 and 38. 
should 'in principle, be confined to those States Parties who have accepted it'. ${ }^{67}$ The DRC Decision acknowledges that Vienna Convention imposed limitations on the ICC Statute could lead to valid questions over when the ICC has jurisdiction over the head of state of a third party and when they retain their immunity.

\section{(ii) Article 98(1)}

In the case of President Bashir, however, the DRC Decision states that this question is answered under art 98(1) of the ICC Statute, which spells out that:

The Court may not proceed with a request for surrender or assistance which would require the requested State to act inconsistently with its obligations under international law with respect to the State or diplomatic immunity of a person or property of a third State, unless the Court can first obtain the cooperation of that third State for the waiver of the immunity.

Under art 98(1), when a State Party is called upon to act inconsistently with its international obligations to a non-state party, in this case 'arising from the decision of the African Union "to respect the immunities that come with [President Bashir's] position of Head of State", ${ }^{68}$ the ICC is first required to secure the cooperation of the non-state party to waive any immunity attached to their head of state.

\section{(iii) UN Security Council Resolution 1593}

However, the DRC Decision claims that through Resolution 1593, ${ }^{69}$ the Security Council has decided that the 'Government of Sudan ... shall cooperate fully with and provide any necessary assistance to the Court and the Prosecutor pursuant to this resolution' ${ }^{70}$ As such, the 'cooperation' required under art 98(1) was secured through Resolution 1593, as the Security Council had 'implicitly waived the immunities granted to Omar Al Bashir under international law and attached to his position as a Head of State'. ${ }^{71}$

The DRC Decision concludes that, by securing Sudan's cooperation, no inconsistency existed in regards to the DRC and their obligation to carry out the arrest warrants issued for President Bashir and that 'the DRC cannot invoke any other decision, including that of the African Union, providing for any obligation to the contrary'.72 The DRC Decision underlines that ' $[\mathrm{h}] \mathrm{ad}$ the Court found any legal impediment (procedural or substantive) to the execution of the pending requests for arrest and surrender of Omar Al Bashir, it would have explicitly ruled to that effect' ${ }^{\prime}{ }^{73}$

70 DRC Decision (International Criminal Court, Pre-Trial Chamber II, Case No ICC-02/05-01/09-1, 9 April 2014) [29] (emphasis altered).

71 Ibid.

72 Ibid [31].

73 Ibid [22]. 


\section{(b) Summary}

On this basis it was communicated to the Ambassador of South Africa during the 12 June 2015 meeting that 'there is no ambiguity in the law', and since the Court's finding in the DRC Decision 'settled the very same matter', the international obligation vis-à-vis the arrest warrants for President Bashir 'applies squarely to the Republic of South Africa as well'. ${ }^{74}$

In his decision on South Africa, Judge Tarfusser made it clear that 'the consultation between the Court and the Republic of South Africa under article 97 ... do not trigger any suspension or stay of this standing obligation', and reiterated 'that the Republic of South Africa is under the obligation to immediately arrest and surrender Omar Al Bashir as soon as on its territory. ${ }^{75}$

\section{The 13 June 2015 Consultation Pursuant to Article 97}

Subsequently, on 13 June 2015, the Chief State Law Adviser at the Department of Justice and Constitutional Development of the Republic of South Africa arrived at The Hague to 'engage in the consultations foreseen by Article 97'.76 Article 97 of the ICC Statute stipulates that when a state receives a request from the ICC in which it identifies problems 'which may impede or prevent the execution of the request, that State shall consult with the Court without delay in order to resolve the matter'. Accordingly, the Chief State Law Adviser was provided with transcripts of the 12 June 2015 meeting and the DRC Decision. It was reiterated to him that 'South Africa was under an obligation to arrest [President Bashir]'.77

On the same day, a request for an order further clarifying whether art 97 consultations with South Africa had concluded and that the Republic of South Africa was under the obligation to immediately arrest and surrender President Bashir was submitted by the ICC Prosecutor and a responding decision following this request was issued by Judge Tarfusser. ${ }^{78}$ In this decision Judge Tarfusser determined that '[a]s there exists no issue which remains unclear or has not already been explicitly discussed and settled by the Court, the consultations under article 97 of the Statute between the Court and the Republic of South Africa have therefore ended'. ${ }^{79}$

Judge Tarfusser concluded in unequivocal terms that it is plain that 'there is no ambiguity in the law and that the Republic of South Africa is under the obligation 02/05-01/09, 13 June 2015) [5], [8] (emphasis added).

75 Ibid.

76 Prosecutor $v$ Al Bashir (Registry Report on the Consultations Undertaken under Article 97 of the Rome Statute by the Republic of South Africa and the Departure of Omar Al Bashir from South Africa on 15 June 2015) (International Criminal Court, Pre-Trial Chamber II, Case No ICC-02/05-01/09-1, 17 June 2015) [3] ('Registry Report').

77 Ibid.

78 See PTC II Decision of 13 June 2015 (International Criminal Court, Pre-Trial Chamber II, Case No ICC-02/05-01/09, 13 June 2015). Ibid [8]. 
to arrest and surrender to the Court Omar Al Bashir' and that '[t]he Republic of South Africa is already aware of this statutory duty and a further reminder is unwarranted'. ${ }^{80}$ Additionally, 'the ICC Prosecutor Fatou Bensouda was quoted by Associated Press as saying that, "We've been in contact and we are basically reminding them of their obligation under the Rome Statute to have him arrested if he gets to South Africa", ${ }^{81}$

\section{B Response to the Arrest Warrants by South Africa's Judiciary}

\section{The 14-15 June 2015 Proceedings}

After confirmation that President Bashir had arrived in South Africa on Sunday, 14 June 2015, the Southern Africa Litigation Centre ('SALC') launched urgent proceedings against 12 respondents before the High Court of South Africa, Gauteng Division, Pretoria, seeking a number of orders aimed at arresting President Bashir, 82 including an order '[c]ompelling the Respondents forthwith to take all reasonable steps to provisionally arrest President Bashir in terms of the Implementation of the Rome Statute of the International Criminal Court Act 27 of 2002' and an order '[c]ompelling the Respondents to prevent President Bashir from leaving the country without taking reasonable steps to facilitate his arrest in terms of domestic and international laws' ${ }^{83}$

Subsequently, advocate I Ellis, who appeared for the respondents to the application presented to the Court "that the Cabinet had taken a decision to grant President Bashir immunity from arrest, and that this decision "trumped" the Government's duty to arrest the President on South African soil in terms of two warrants of arrest issued by the ICC' and requested an adjournment to prepare a full argument. ${ }^{84}$ Fabricius J, 'mindful of the fact that the African Union Summit, which President Bashir was attending, would be in session for the whole of that day and for the entire day on Monday', ${ }^{85}$ granted an adjournment until 11:30 on Monday 15 June 2015, but issued an interim order which in its pertinent part stated 'President Omar Al Bashir of Sudan is prohibited from leaving the Republic of South Africa

80 Ibid [5], [10].

81 'ICC Judges Reject South Africa's Argument Against Arresting Sudanese President', Sudan Tribune (online), 13 June $2015<$ http://www.sudantribune.com/spip.php?iframe\&page=imprimable\&id_ article $=55331>$.

82 Owen Bowcott and Jamie Grierson, 'Sudan President Barred from Leaving South Africa', The Guardian (online), 15 June $2015<$ http://www.theguardian.com/world/2015/jun/14/sudan-presidentomar-al-bashir-south-africa-icc $>$. For information about President Bashir's actual arrival in South Africa for the $25^{\text {th }}$ AU Summit, see, eg, Nomfundo Manyathi-Jele, 'Court Criticised Over 'Al-Bashir' Judgment', De Rebus (online), 23 July $2015<$ http://www.derebus.org.za/court-criticised-al-bashirjudgment/>.

83 South Africa Litigation Centre, Notice of Motion in the High Court of South Africa in the Case of Southern Africa Litigation Centre v Minister of Justice and Constitutional Development and Others (14 June 2015) [4]-[5] <http://www.southernafricalitigationcentre.org/1/wp-content/ uploads/2015/06/Notice-of-Motion-and-Founding-Affidavit.pdf $>$.

84 Southern Africa Litigation Centre [2015] 5 SA 1, 5 [5] (High Court).

85 Ibid 5-6 [6]. 
until a final order is made in this application, and the Respondents are directed to take all necessary steps to prevent him from doing so'. ${ }^{86}$

On 15 June 2015, the application continued before a Full Court consisting of Mlambo JP, Ledwaba DJP and Fabricius J. ${ }^{87}$ Importantly, the Court specifically requested advocate Mokhari SC, appearing for the respondents, 'to provide an indication whether President Bashir was still in the country', ${ }^{88}$ to which advocate Mokhari SC provided reassurances that President Bashir was still in South Africa, which he repeated throughout the hearing. ${ }^{89}$ These reassurances, however, contradict media reports, for example, those made by The Guardian and The New York Times, both of which reported that President Bashir left South Africa on the morning of 15 June 2015. The New York Times reported that President Bashir's presidential jet 'left a South African military airport near Pretoria, the capital, unhindered by the South African authorities' on Monday morning, 'just hours before a South African court ruled that the government was legally required to arrest him'. ${ }^{90}$ The Guardian was more specific, reporting that 'Bashir's plane took off from Waterkloof military airfield outside Pretoria’ early on Monday. ${ }^{91}$

Around 15:00, having heard arguments the Court handed down the order that 'the conduct of the Respondents, to the extent that they have failed to take steps to arrest and/or detain the President of the Republic of Sudan Omar Hassan Ahmad Al Bashir, is inconsistent with the Constitution of the Republic of South Africa, 1996, and invalid'. ${ }^{92}$ Furthermore, the Court ordered that 'the Respondents are forthwith compelled to take all reasonable steps to prepare to arrest President Bashir ... and detain him, pending a formal request for his surrender from the International Criminal Court'. ${ }^{93}$ The reasons for this order were explained by the Court at a hearing on 24 June 2015 and are discussed below.

It is reported in the media that immediately after the handing down of the order for President Bashir's arrest the Court was informed that the President had left South Africa. ${ }^{94}$ According to The New York Times, at this time the Attorney for the South African government stated that the 'Government now [had] reliable information that Omar al-Bashir has departed' and that 'the Minister of State Security [had] confirmed an investigation would be conducted into how Bashir left the country'. ${ }^{95}$ Concurrently, Sudan's Minister for Information told reporters

86 Ibid.

87 Ibid 6-7 [7].

88 Ibid 7 [8].

89 Ibid.

90 Norimitsu Onishi, 'Omar Al-Bashir, Leaving South Africa, Eludes Arrest Again', The New York Times (online), 15 June $2015<$ http://www.nytimes.com/2015/06/16/world/africa/omar-hassan-albashir-sudan-south-africa.html?_r=0>.

91 Owen Bowcott, 'Sudan President Omar Al-Bashir Leaves South Africa as Court Considers Arrest', The Guardian (online), 16 June 2015 <https://www.theguardian.com/world/2015/jun/15/south-africato-fight-omar-al-bashirs-arrest-warrant-sudan>.

92 Southern Africa Litigation Centre [2015] 5 SA 1, 4 [2] (High Court).

93 Ibid

94 Ibid 7-8 [9].

95 Registry Report (International Criminal Court, Pre-Trial Chamber II, Case No ICC-02/05-01/09-1, 17 June 2015) [8]. 
that President Bashir was expected back in Khartoum on Monday evening, ${ }^{96}$ meaning President Bashir must have departed South Africa no later than midday.

In the High Court's Judgment of 24 June 2015, it is claimed that '[ $t$ ]he court concluded hearing argument just after 14:30 and handed down the order ... at about 15:00. It is only then that the court was informed by advocate Mokhari SC that President Bashir had left the country. ${ }^{97}$ Advocate Mokhari SC told the Court: 'I have been informed by the government that they have reliable information that President Al-Bashir has departed from the Republic. ${ }^{98}$

After receiving confirmation of President Bashir's departure, Mlambo JP stated that 'the government had violated the South African High Court's order to bar [President] Bashir from leaving the country' and ordered that the Minister in the Office of the Presidency and the Minister of State Security 'file an affidavit within seven days explaining the circumstances under which President Bashir managed to fly out of this country despite the explicit court order prohibiting this. ${ }^{99}$

In the corresponding 'Respondents' Explanatory Affidavit', ${ }^{100}$ Mkuseli Apleni, Director General of the Department of Home Affairs, claimed to have contacted immigration officials at Waterkloof Air Force Base in response to media claims that President Bashir had departed from there. He stressed that he had been informed that the passport of President Bashir was not one of the passports that were "handed to immigration for processing of the persons that were on board the flight (of the presidential jet SUDAN01). ${ }^{101}$ Apleni went on to explain the immigration protocols and procedures involved for the departure of 'VIP flights', expounding that immigration officers were not provided with passenger lists and that 'passengers on VIP flights do not personally appear before the Immigration Officer'. ${ }^{102}$

Apleni made clear that these procedures were adhered to 'in respect of Sudanese flight SUDAN01 on 15 June 2015 , ${ }^{103}$ before concluding that 'it would therefore appear from the above that President Bashir departed from the Republic [of South Africa] without his passport being presented to the Immigration Officer ${ }^{104} \mathrm{He}$ also emphasised that the Department of International Relations and Cooperation, in conjunction with the South African Police Service, was responsible for facilitating the itinerary and transport of a visiting dignitary. However, Apleni failed to provide an explanation of how these departments were unaware of the movement of President Bashir to the air force base. Furthermore, he did

96 Onishi, above n 90.

97 Southern Africa Litigation Centre [2015] 5 SA 1, 7 [9] (High Court).

98 Adam Wakefield, 'Court to Give Reasons for Al-Bashir Ruling', News24 (online), 24 June $2015<$ http:// www.news24.com/SouthAfrica/News/Court-to-give-reasons-for-A1-Bashir-ruling-20150624>.

99 Southern Africa Litigation Centre [2015] 5 SA 1, 7 [9] (High Court).

100 Respondents, 'Respondents' Explanatory Affidavit', Submission in Southern Africa Litigation Centre v Minister of Justice and Constitutional Development and Others, 27740, 25 June 2015.

101 Ibid 4.

102 Ibid 7.

103 Ibid.

104 Ibid 9. 
not address the question of how immigration officials failed to flag the unusual absence of President Bashir from the departing Sudanese delegation either. The following week, on 24 June 2015, a hearing was held for the explanation of the decision by the Court that the South African authorities are 'compelled to take all reasonable steps to prepare to arrest President Bashir'. ${ }^{105}$

\section{The 24 June 2015 Hearing}

During the 24 June hearing, the Court acknowledged that 'South African authorities [we]re enjoined to cooperate with the ICC ... to effect the arrest and provisional arrest of persons suspected of war crimes, genocide and crimes against humanity, ${ }^{106}$ and explained the propositions on which their decision was based. According to the Court, President Bashir could not claim head of state immunity. The Court reminded that under South African law, diplomatic immunity was governed by the Diplomatic Immunities and Privileges Act 37 of 2001 (South Africa) ('Immunities Act'). ${ }^{107}$ Pursuant to s 4 of this Act, heads of state are immune from civil and criminal jurisdiction 'to the extent afforded to them under customary international law, or as agreed to between South Africa and the relevant State party, or as are conferred on them by the Minister of International Relations'. ${ }^{108}$

As far as customary international law was concerned, the Court held that 'the [ICC Statute] expressly provides that heads of state do not enjoy immunity under its terms. Similar provisions are expressly included in the Implementation Act' ${ }^{109}$ Hence, 'immunity that might otherwise have attached to President Bashir based on customary international law as head of state' does not apply in this instance. ${ }^{110}$

Additionally, the Court referred to the above-discussed PTC II Decision of 13 June 2015. ${ }^{111}$ To reiterate, this decision expressly confirmed that 'the immunities granted to President Bashir under international law and attached to his position as head of state have been implicitly waived by the Security Council', and that South Africa was consequently 'under the obligation to arrest and surrender' him. ${ }^{12}$

Moreover, the Court stressed that the agreement between South Africa's Minister of International Relations and the AU Commission on Material and Technical Organisation ('AU Commission') 'to grant privileges and immunity to "Members of the Commission and the Staff Members, [and] the delegates and other representatives of Inter-Governmental Organisations" attending the ... AU Summit' ('the Host Agreement') does not confer immunity to President

105 Southern Africa Litigation Centre [2015] 5 SA 1, 3 [2] (High Court).

106 Ibid 10 [11].

107 Ibid 13 [17], 18 [28].

108 Ibid 19 [28.2].

109 Ibid 19 [28.8].

110 Ibid.

111 PTC II Decision of 13 June 2015 (International Criminal Court, Pre-Trial Chamber II, Case No ICC02/05-01/09-1, 13 June 2015).

112 Ibid [5], [9]. 
Bashir. ${ }^{113}$ The Host Agreement provides that the South African Government "'shall accord the Members of the Commission and Staff Members, the delegates and other representatives of Inter-Governmental Organizations attending the [AU Summit] the privileges and immunities set forth in Sections C and D, Articles $\mathrm{V}$ and VI of the General Convention on the Privileges and Immunities of the OAU". ${ }^{114}$ Therefore, in the Court's view, the Host Agreement on its terms, only 'confers immunity on members and staff of the African Union Commission, and on delegates and representatives of Inter-Governmental Organisations. It does not confer immunity on Member States or their representatives or delegates'. ${ }^{115}$ Importantly, it 'does not confer immunity on heads of state'. ${ }^{116}$

Furthermore, the Host Agreement was concluded under s 5(3) of the abovementioned Immunities Act, which governs diplomatic immunity under South African law. The Immunities Act provides that 'any organisation recognised by the Minister for purposes of this section and any official of such organisation enjoy such privileges and immunities as may be provided for in any agreement entered into with such organisation or as may be conferred on them by virtue of Section 7(2),. ${ }^{117}$ This provision only deals with the conferral of immunity to 'organisations', defined under the Immunities Act as 'an intergovernmental organisation of which two or more states or governments are members and which the Minister has recognised for the purposes of this Act'. ${ }^{118}$ Therefore, the Immunities Act does not allow for the conferral of immunity to heads of state. It follows that the Host Agreement does not confer immunity on President Bashir either. $^{119}$

The Court opined that the African Union Convention or Host Agreement could not be relied upon to confer immunity to President Bashir as they did not 'trump' South Africa's obligations under the Implementation Act or the ICC Statute. ${ }^{120}$ The Court held that decisions of the AU are 'persuasive, at best' under South African domestic law. ${ }^{121}$ In the Court's view, the Immunities Act 'does not domesticate the OAU Convention. It is therefore not binding in South Africa, and the structures, staff and personnel of the AU consequently do not automatically enjoy privileges and immunity in South Africa'. ${ }^{22}$ This represents a 'clear choice'

113 Southern Africa Litigation Centre [2015] 5 SA 1, 19 [28.5]. This 'agreement was published in the Government Gazette on 5 June 2015 — just two days before the first AU meetings were due to commence': at ibid.

114 Ibid 23 [30]. See The General Convention on the Privileges and Immunities of the Organization of African Unity, 1000 UNTS 394 (signed and entered into force 25 October 1965) art V which provides that '[r]epresentatives of Member States' shall be accorded, inter alia, 'immunity from personal arrest or detention' and 'such other privileges, immunities and facilities ... as diplomatic envoys enjoy'.

115 Southern Africa Litigation Centre [2015] 5 SA 1, 20 [28.10.1].

116 Ibid 19 [28.7].

117 Immunities Act s 5(3).

118 Ibid s 1(iv).

119 Southern Africa Litigation Centre [2015] 5 SA 1, 19 [28.7], 20 [28.11].

120 Ibid 21 [28.13].

121 Ibid 21 [28.13.3].

122 Ibid 19 [28.4]. 
to not confer 'blanket immunity' on representatives of member states who attend AU meetings in South Africa. ${ }^{123}$ Citing the previously discussed DRC Decision, the Court stressed that 'the Respondents' argument based on immunities provided for in the host agreement and on AU membership is misguided'. ${ }^{124}$

Finally, the Court observed that the question of necessity was never raised by the respondents, that is, that the respondents failed to address the question of whether 'the government of South Africa was justified in disobeying the order of 14 June 2015, or ignoring its domestic and international obligations in terms of the Implementation Act' ${ }^{125}$ The Court held that 'on a common sense approach, there are clear indications that the [interim order barring President Bashir from leaving South Africa] was not complied with'. ${ }^{126}$

Based on these findings, as well as based on the fact that the ICC Statute had been incorporated into the Constitution of the Republic of South Africa Act 1996 (South Africa) upon ratification, the Court concluded that the failure of the respondents to detain President Bashir was 'inconsistent with the [Constitution of the Republic of South Africa Act 1996 (South Africa)], and invalid'. ${ }^{127}$

\section{Response to the Arrest Warrants by South African Parliament}

The South African Parliament debated the incident in the National Assembly on Tuesday 24 June 2015. Stevens Mokgalapa, from the Democratic Alliance, said '[ $\mathrm{t}$ ]he ANC government led by Jacob Zuma has committed a crime of assisting a wanted man to run from the law'. ${ }^{28}$ The Inkatha Freedom Party's Albert Mncwango revealed that '[r]eports emerging over the last few days allege that it was agreed beforehand that Omar al-Bashir would be protected by all means necessary, which clearly shows trampling on the Constitution and the rule of law'. ${ }^{129}$ On the other hand, a senior South African Minister, Jeff Radebe contended that the ICC's rules about arresting a serving head of state were contradictory and he accused the ICC of not acting in good faith vis-à-vis ICC Statute art 97 consultations. ${ }^{130}$ After the Cabinet meeting of 24 June 2015, the government indicated that it may consider withdrawing from the ICC if all other remedies

123 Ibid 21 [28.13.2].

124 Ibid 26 [32].

125 Ibid 26-7 [33].

$126 \operatorname{Ibid} 29$ [37.2].

127 Ibid 3 [2].

128 Barry Bateman, 'High Court: Allowing Al-Bashir to Leave Was a Violation of the Law', Eyewitness News (online), 24 June $2015<$ http://ewn.co.za/2015/06/24/High-Court-Allowing-al-Bashir-to-leavewas-a-violation-of-the-law>.

129 Ibid.

130 'South Africa May Leave ICC over Bashir Arrest Row', BBC News Africa (online), 25 June 2015, $<$ http://www.bbc.com/news/world-africa-33269126>. 
are exhausted. ${ }^{131}$ In the government's view President Bashir enjoyed diplomatic immunity and it had done nothing wrong by not arresting him. ${ }^{132}$

\section{HEAD OF STATE IMMUNITY UNDER INTERNATIONAL LAW}

International law has traditionally provided immunity for heads of state and other government officials for their activities when subject to litigation action in foreign domestic courts. Doing so reflects both pragmatic and theoretical objectives by ensuring a measure of freedom in the conduct of international affairs and recognition of the horizontal relationship that exists between states and their respective sovereignties under international law. While this concept of immunity continues to faithfully represent current principles of international law, its durability has been tested in numerous fora. As developed in this part, while established immunities are still asserted and recognised, there is a growing correlative acceptance by the international community that sovereign immunity is not so absolute, at least where crimes under international law have been committed.

\section{A Rationale for Sovereign Immunity}

The basis for the general rule of sovereign immunity is articulated in the famous US Supreme Court decision Schooner Exchange v McFaddon, where Marshall CJ described the immunity in the following way:

This full and absolute territorial jurisdiction being alike the attribute of every sovereign, and being incapable of conferring extraterritorial power, would not seem to contemplate foreign sovereigns nor their sovereign rights as its objects. One sovereign being in no respect amenable to another; and being bound by obligations of the highest character not to degrade the dignity of his nation, by placing himself or its sovereign rights within the jurisdiction of another ... This perfect equality and absolute independence of sovereigns, and this common interest impelling them to mutual intercourse, and an interchange of good offices with each other, have given rise to a class of cases in which every sovereign is understood to waive the exercise of a part of that complete exclusive territorial jurisdiction, which has been stated to be the attribute of every nation. ${ }^{133}$

More recently, the International Court of Justice ('ICJ'), in the case of Germany $v$ Italy, has reinforced the general rule of head of state immunity as a feature of sovereign equality. ${ }^{134}$ In such circumstances senior state officials derive functional immunities for actions they undertake in the course of duty for the state. Hence

131 Ibid.

132 Ibid.

13311 US (7 Cranch) 116, 137 (1812).

134 Jurisdictional Immunities of the State (Germany v Italy: Greece Intervening) (Judgment) [2012] ICJ Rep 99, 123-124 [57] ('Germany v Italy'). 
in $R v$ Bow Street Metropolitan Stipendiary Magistrate; Ex parte Pinochet Ugarte [No 3], Lord Millet described the basis for functional immunities as being a 'subject matter immunity' operating to prevent official and government acts being called into question by proceedings in a foreign jurisdiction. ${ }^{135}$ It is a subject matter immunity that is available to heads of state/government as well as government ministers, military commanders, chiefs of police, as well as subordinate public officials. ${ }^{136}$

\section{Immunity Ratione Materiae}

Under existing tenets of international law, the immunity is also available to former office holders but only in relation to government or official acts. It is a well-established substantive immunity under international law characterised as functional or organic immunity (ratione materiae) and has found consistent support from both international and domestic courts. ${ }^{137}$

This doctrine grants immunity from criminal and civil proceedings in a foreign domestic court and applies to protect the state and, only incidentally, the individual concerned from such proceedings. While attaching to official or government acts, it does not apply to actions taken privately or otherwise not consistent with official functions. A key issue under this head of immunity, therefore, is whether an act in question was undertaken in an official capacity or a personal one. If the latter, then the immunity does not apply to protect the individual from foreign court proceedings. Moreover, even if the former, it does not absolve the state from more generally attracting state responsibility for action undertaken on the plane of international law, even if the individual is not susceptible to domestic court action.

\section{5 [2000] 1 AC 147, 269 ('Pinochet').}

136 Ibid. Pursuant to ICC Statute art 48, the ICC and its staff also enjoy some privileges and immunities necessary to exercise their functions independently and without interference from states. Commentary on ICC Statute art 48 describes the scope of official immunity recognised by art 48 as a 'sliding scale' of privileges and immunities, from full diplomatic privileges and immunities being afforded to judges, the registrar and the prosecutor and deputy prosecutor when they are on court business, to a limited reference to 'treatment as is necessary' given to counsel, experts, witnesses, and other persons required to be present at the seat of the Court': see, Yvonne McDermott, 'Article 48 - Privileges and Immunities' in Mark Klamberg (ed), The Commentary on the Law of the International Criminal Court (June 2016) $398<$ https://www.casematrixnetwork.org/cmnknowledge-hub/icc-commentary-clicc/commentary-rome-statute/commentary-rome-statute-part4/\#c3766>. The Commentary also highlights some limitations of official immunity. It notes that it is 'most unfortunate' that the same functional immunity accorded to the Office of the Prosecutor and the staff of the Registry is not extended to defence counsel or members of defence investigating teams within the meaning of ICC Statute art 48(3). The Commentary illustrates this shortcoming by the ICTR example where a defence counsel practicing before this tribunal was arrested and detained by Rwanda in 2011 on charge of 'genocide denial', linked to statements made in the course of his client's defence, and by the ICC example where four members of ICC staff acting on behalf of Saif Gaddafi were detained by the Libyan authorities in 2012: see McDermott, above n 136, 400.

137 See, eg, Prosecutor v Tihomir Blaškić (Judgment on the Request of the Republic of Croatia for Review of the Decision of Trial Chamber II of 18 July 1997) (International Criminal Tribunal for the former Yugoslavia, Case No IT-95-14-AR, Appeals Chamber, Case No IT-95-14-A, 29 October 1997) ('Blaškić); Arrest Warrant of 11 April 2000 (Democratic Republic of the Congo v Belgium) (Judgment) [2002] ICJ Rep 3 ('Arrest Warrant'); Pinochet [2000] 1 AC 147; Attorney General of Israel v Adolf Eichmann (1962) 36 ILR 5 (Israel Supreme Court) ('Eichmann'). 


\section{Immunity Ratione Personae}

In contrast to functional state immunity (ratione materiae) discussed above, is the parallel concept of personal sovereign immunity (ratione personae). This immunity is procedural in nature and is narrower in scope. ${ }^{138}$ It is concerned with the personal status of the individual. Hence, it is intended to apply only to some categories of state officials, namely 'serving heads of state and heads of diplomatic missions, their families and servants,',139 as well as serving ministers of foreign affairs, and provides absolute immunity ensuring that while still in office, a head of state or head of a diplomatic mission/foreign affairs minister is not liable to be arrested or detained on any ground whatsoever.

\section{The Relationship between Immunity Ratione Materiae and Immunity Ratione Personae}

The relationship between the two immunities is close and they effectively overlap as the individual may also have functional immunity for their actions. As Cassese has observed, "the two classes of immunity coexist and somewhat overlap as long as a state official who may also invoke personal or diplomatic immunities is in office'. ${ }^{140}$

While these two forms of immunity, the functional (ratione materiae) and the personal (ratione personae), overlap there are important distinctions. The former can be waived on the basis of an inquiry by the relevant court or tribunal into the quality of the actions undertaken. Hence as outlined above, private or nonofficial actions are not covered by the immunity. Conversely, the latter personal immunity attaches to a much narrower band of high official and does attach (as a procedural right) to any actions of the high official. This distinction was emphasised by Lord Millet in the case of Pinochet where he noted that the immunity 'is not available to serving heads of government who are not also heads of state, military commanders and those in charge of the security forces, or their subordinates. It would have been available to Hitler but not to Mussolini or Tojo'. ${ }^{141}$ As deeply rooted as this immunity is within the fabric of relations between states, it only applies inter se between states and their national courts.

\section{B Lifting of Functional Immunity with Respect to International Crimes in Domestic Courts}

The lifting of functional immunity (ratione materiae) within domestic legal proceedings has occurred with a level of consistency in the recent past. In the 1962 Eichmann case, for example, the Israel Supreme Court expressly stated

\footnotetext{
138 It could be argued that all immunities are in some sense procedural.

139 Pinochet [2000] 1 AC 147, 268.

140 Antonio Cassese, International Criminal Law (Oxford University Press, $2^{\text {nd }}$ ed, 2008) 304 (emphasis altered).

141 Pinochet [2000] 1 AC 147, 268.
} 
that functional immunity could not prevent a foreign court from trying a person charged with crimes against humanity. ${ }^{142}$ Notably, in the Eichmann case the Supreme Court defined crimes against humanity in the wider sense as including genocide and war crimes:

There is no basis for the doctrine when the matter pertains to acts prohibited by the law of nations, especially when they are international crimes of the class of 'crimes against humanity' (in the wide sense). Of such odious acts it must be said that in point of international law they are completely outside the 'sovereign' jurisdiction of the State that ordered or ratified their commission, and therefore those who participated in such acts must personally account for them and cannot shelter behind the official character of their task or mission, or behind the 'Laws' of the state by virtue of which they purported to act. ${ }^{143}$

The Court in that instance made a logical and legally sustainable conclusion that the commission of crimes against humanity as understood under international law could not be consistent with 'official duties' to sustain a plea of functional immunity. The case stands as a significant touchstone in this area of specialisation.

The finding of the Israel Supreme Court was subsequently adopted by the House of Lords in Pinochet ${ }^{144}$ Referring to the Eichmann judgment, Lord Millet reasoned that the commission of international crimes of universal jurisdiction deprived a state official of the protection of functional immunity. ${ }^{145}$ In that instance the Court determined that as a former head of state, Senator Pinochet's actions in authorising acts of torture were not consistent with 'official duties' and hence did not attract immunity ratione materiae. ${ }^{146}$ This was based on the firm, but narrow, ground that international crimes attracting universal jurisdiction cannot be consistent with official capacity. Significantly, the Court opined that this would not apply to 'ordinary' crimes of murder and conspiracy to commit murder ${ }^{147}$ which do not have any particular international status.

Significantly, however, the House of Lords in the Pinochet case also made clear that personal immunity (ratione personae) would have protected Pinochet had he still been acting as head of state at the time of the proceedings. ${ }^{148}$ This conclusion was supported by the ICJ in the subsequent Arrest Warrant case, where the Court surveyed existing precedent and practice from national jurisdictions and determined that:

It has been unable to deduce from this practice that there exists under customary international law any form of exception to the rule according immunity from criminal jurisdiction and inviolability to incumbent Ministers for Foreign Affairs, 
where they are suspected of having committed war crimes or crimes against humanity. ${ }^{149}$

The Court did make a number of additional observations regarding this conclusion, pointedly stating that immunity did not mean impunity. ${ }^{150}$ While immunity of the ratione personae variety still existed as a bar to prosecuting a relevant serving minister of state, the Court pointed to a number of ways in which such persons even in this category might still be prosecuted for their crimes. These included the possibility that immunity could be waived by the relevant national government itself in relation to the foreign proceeding; that such persons may be prosecuted by their own states even if still serving; that upon ceasing to serve as an incumbent relevant minister of state then foreign jurisdictions may exercise prosecutorial discretion; and finally, that:

an incumbent or former Minister for Foreign Affairs may be subject to criminal proceedings before certain international criminal courts, where they have jurisdiction. Examples include the ... International Criminal Court ... [whose] Statute expressly provides, in Article 27, paragraph 2, that '[i]mmunities or special procedural rules which may attach to the official capacity of a person, whether under national or international law, shall not bar the Court from exercising its jurisdiction over such a person'. ${ }^{151}$

This last possibility is one that has emerged with increasing frequency in the last few decades. It was discussed in Part III of this article in relation to Sudan and is also the focus of the following analysis.

\section{International Jurisdiction and the Question of Sovereign Immunities}

As identified by the ICJ in the Arrest Warrant case, objections to one state sitting in judgement of another state through domestic processes (par in parem non habet imperium) are avoided where the tribunal or court considering a matter is one that has an international character. Acting in this supranational capacity, the nature of such proceedings avoids the theoretical stigma of competing sovereignties and equals sitting in judgement of each other.

Since the Second World War, legal instruments establishing international courts and tribunals have generally excluded a plea of both functional and personal immunity. At customary international law, a state official cannot plead their official position as a bar to criminal liability in respect of international crimes in the nature of war crimes, crimes against humanity, genocide and aggression, which attract universal jurisdiction. The rule prohibiting such a plea saw its genesis in the international legal proceedings relating to criminal liability that followed the Second World War. 


\section{London Agreement}

On 8 August 1945 the Agreement for the Prosecution and Punishment of the Major War Criminals of the European Axis was signed in London by France, the UK, the US and the Soviet Union. ${ }^{152}$ The London Agreement established the International Military Tribunal for the trial of war criminals whose offences had no particular geographical location and set out the terms of the Charter of the Tribunal. 19 other states (including Australia) later expressed their adherence to the London Agreement. Article 7 of the Charter of the International Military Tribunal, annexed to the London Agreement, provided that:

The official position of defendants, whether as Heads of State or responsible officials in Government Departments, shall not be considered as freeing them from responsibility or mitigating punishment. ${ }^{153}$

The International Military Tribunal made the following statement with respect to art 7:

The principle of international law, which under certain circumstances, protects the representatives of a state, cannot be applied to acts which are condemned as criminal by international law. The authors of these acts cannot shelter themselves behind their official position in order to be freed from punishment in appropriate proceedings. Article 7 of the Charter expressly declares: 'The official position of Defendants, whether as heads of State, or responsible officials in Government departments, shall not be considered as freeing them from responsibility, or mitigating punishment.' On the other hand the very essence of the Charter is that individuals have international duties which transcend the national obligations of obedience imposed by the individual state. He who violates the laws of war cannot obtain immunity while acting in pursuance of the authority of the state if the state in authorizing action moves outside its competence under international law. ${ }^{154}$

\section{Contemporary International Tribunals}

This precedent was reflected in the statutes of contemporary international tribunals dealing with crimes under international law, specifically the Statute of the International Criminal Tribunal for the former Yugoslavia, ${ }^{155}$ and the Statute

152 Agreement for the Prosecution and Punishment of the Major War Criminals of the European Axis, and Charter of the International Military Tribunal, signed 8 August 1945, 82 UNTS 280 (entered into force 8 August 1945) ('London Agreement').

153 Ibid annex ('Charter of the International Military Tribunal') art 7.

154 Judgement of the International Military Tribunal for the Trial of German Major War Criminals, Nuremberg Trial Proceedings (1947) vol 1, 223 (emphasis added). The UN General Assembly passed a resolution affirming the judgment and the Charter of the International Military Tribunal as reflecting international law: see Affirmation of the Principles of International Law Recognized by the Charter of the Nuremberg Tribunal, GA Res 95(I), UN GAOR, $1^{\text {st }}$ sess, $55^{\text {th }}$ plen mtg (11 December 1946).

155 SC Res 827 , UN SCOR, $48^{\text {th }}$ sess, $3217^{\text {th }} \mathrm{mtg}$, UN Doc S/RES/827 (25 May 1993), as amended by SC Res 1877 , UN SCOR, $64^{\text {th }}$ sess, $6155^{\text {th }} \mathrm{mtg}$, UN Doc S/RES/1877 (7 July 2009) ('ICTY Statute'). 
of the International Criminal Tribunal for Rwanda. ${ }^{156}$ ICTY Statute art 7(2) and, correspondingly, ICTR Statute art 6(2) provide that:

The official position of any accused person, whether as head of state or government or as a responsible government official, shall not relieve such person of criminal responsibility nor mitigate punishment.

The ICTY Trial Chamber in the Decision on Preliminary Motions in the Milošević case addressed the defence argument that the Tribunal lacked competence by reason of Milošević's status as former President. ${ }^{157}$ The Trial Chamber discussed, inter alia, the nature of the rule lifting functional and/or personal immunities for international crimes and concluded that art 7(2) of the ICTY Statute ("the official position of any accused person, whether as Head of State or Government or as a responsible Government official, shall not relieve such person of criminal responsibility nor mitigate punishment') reflected customary international law whose heritage could be traced to the Nuremberg and Tokyo Charters. ${ }^{158}$ Moreover, the Tribunal noted that this rule had found expression in numerous contemporary instruments, including the ICTR Statute, the Statute of the Special Court for Sierra Leone, the Draft Code of Crimes against the Peace and Security of Mankind and the ICC Statute. ${ }^{159}$

In respect of the ICC Statute, art 27 states:

1. This Statute shall apply equally to all persons without any distinction based on official capacity. In particular, official capacity as a Head of State or Government, a member of a Government or parliament, an elected representative or a government official shall in no case exempt a person from criminal responsibility under this Statute, nor shall it, in and of itself, constitute a ground for reduction of sentence.

2. Immunities or special procedural rules which may attach to the official capacity of a person, whether under national or international law, shall not bar the Court from exercising its jurisdiction over such a person.

The inclusion of such a sweeping articulation of liability in an instrument intending to have broad international scope demonstrates the resolve at international law to ensure that immunity should not equal impunity. As art 27 demonstrates, the ICC is able to prosecute incumbent and former state officials for alleged commission of international crimes as (1) functional immunities cannot be pleaded with respect to international crimes of universal jurisdiction and (2) immunities, both functional and personal, are 'horizontal immunities', and cannot be pleaded before international, as opposed to domestic, courts and tribunals.

156 SC Res 955 , UN SCOR, $49^{\text {th }}$ sess, $3453^{\text {rd }} \mathrm{mtg}$, UN Doc S/RES/955 (8 November 1994) annex ('ICTR Statute').

157 Prosecutor $v$ Slobodan Milošević (Decision on Preliminary Motions) (International Criminal Tribunal for the former Yugoslavia, Case No IT-02-54, 8 November 2001) [26]-[34] ('Milošević'). Slobodan Milošević served as President of the Federal Republic of Yugoslavia from 1997 until 2000. In May 1999, he was indicted by the ICTY and arrested in 2001. The trial began in February 2002. On 11 March 2006, he was found dead in his prison cell.

158 Ibid [29].

159 Ibid [30]. 


\section{APPLYING THE RULES ON HEAD OF STATE IMMUNITY TO THE BASHIR CASE}

\section{A An Overview}

While ICC Statute art 27 plainly allows for the ICC to exercise jurisdiction over heads of state for parties to the ICC Statute, the ICC Pre-Trial Chamber, significantly, found that under customary international law Bashir, as the serving President of Sudan, did not enjoy immunity from prosecution before the ICC. This was the Court's finding notwithstanding the fact that Sudan was not a party to the ICC Statute. In the Decision on the Prosecution's Application for a Warrant of Arrest case, the Pre-Trial Chamber stated that:

the Chamber considers that the current position of Omar Al Bashir as Head of a state which is not a party to the Statute, has no effect on the Court's jurisdiction over the present case. ${ }^{160}$

The conclusion appears to reaffirm that provisions in art 27 are representative of customary international law. While this is certainly an eminently defensible position, it does not immediately answer the question of how the ICC can generally exercise jurisdiction against the head of state of a non-party to the ICC Statute. In this instance, as discussed above in Part III, the matter was referred to the ICC by the UN Security Council and to that end while this triggering mechanism is permitted for individuals of even non-state parties, ${ }^{161}$ the Court will need to navigate carefully what rules and substantive provisions it can apply from the ICC Statute to a defendant of a non-state party. While there is general consensus that this matter is one that should result in ICC action, the way in which it is done can have far-reaching effects to a number of general principles of international law.

\section{B Arguments for Arrest}

Pursuant to a number of instruments and principles of international law South Africa had a clear legal obligation to arrest President Bashir during his attendance of the $25^{\text {th }}$ AU Summit. These derive, inter alia, from South Africa's obligations under the ICC Statute, from South Africa's obligations under the Charter of the United Nations and from South Africa's obligations under the Genocide Convention. 


\section{South Africa's Obligations under the ICC Statute}

South Africa signed the ICC Statute on 17 July 1998 and deposited its instrument of ratification on 27 November 2000. ${ }^{162}$ It follows that South Africa is clearly bound by the ICC Statute. Article 59 of the ICC Statute provides that '[a] State Party which has received a request for provisional arrest or for arrest and surrender shall immediately take steps to arrest the person in question in accordance with its laws'. Article 86 imposes on all State Parties a general obligation to 'cooperate fully with the Court in its investigation and prosecution of crimes within the jurisdiction of the Court'. Further, the preamble to the ICC Statute '[recalls] that it is the duty of every State to exercise its criminal jurisdiction over those responsible for international crimes'.

To restate, a warrant for the arrest of President Bashir was issued by the ICC on 4 March 2009 by Pre-Trial Chamber I for: the war crimes of intentionally directing attacks against civilians and pillage; and for the crimes against humanity of murder, forcible transfer, extermination, rape and torture. ${ }^{163}$ A further warrant for the arrest of President Bashir was issued by the ICC on 12 July 2010 for the crime of genocide. ${ }^{164}$ Subsequently, requests to all States Parties to the ICC Statute for the arrest and surrender of President Bashir were issued by the Registry of the ICC on 6 March 2009 and 21 July 2010. ${ }^{165}$

In anticipation of the AU Summit in June 2015, the ICC reminded South Africa of its obligation to arrest President Bashir on 28 May 2015. ${ }^{166}$ South Africa subsequently requested a meeting with the ICC pursuant to art 97 of the ICC Statute. ${ }^{167}$ During this meeting South Africa was reminded of the Court's earlier ruling on this issue, in respect of the DRC Decision, and was told repeatedly in

162 International Criminal Court, South Africa (11 March 2003) < https://asp.icc-cpi.int/en_menus/asp/ states\%20parties/african\%20states/Pages/south\%20africa.aspx $>$.

163 First Arrest Warrant (International Criminal Court, Pre-Trial Chamber I, Case No ICC-02/05-01/09, 4 March 2009) 7-8.

164 Second Arrest Warrant (International Criminal Court, Pre-Trial Chamber I, Case No ICC-02/0501/09-1, 12 July 2010).

165 Prosecutorv Omar Hassan Ahmad Al Bashir (Request to All States Parties to the Rome Statute for the Arrest and Surrender of Omar Al Bashir) (International Criminal Court, Pre-Trial Chamber I, ICC02/05-01/09-7, 6 March 2009); Prosecutor v Omar Hassan Ahmad Al Bashir (Supplementary Request to All States Parties to the Rome Statute for the Arrest and Surrender of Omar Hassan Ahmad Al Bashir) (International Criminal Court, Pre-Trial Chamber I, ICC-02/05-01/09-96, 21 July 2010).

166 PTC II Decision of 13 June 2015 (International Criminal Court, Pre-Trial Chamber II, ICC-02/0501/09-242, 13 June 2015) [3]. This occurred by way of note verbale to the embassy of South Africa in the Netherlands.

167 Ibid [4]. ICC Statute art 97 provides:

Where a State Party receives a request under this Part in relation to which it identifies problems which may impede or prevent the execution of the request, that State shall consult with the Court without delay in order to resolve the matter. Such problems may include, inter alia:

(a) Insufficient information to execute the request;

(b) In the case of a request for surrender, the fact that despite best efforts, the person sought cannot be located or that the investigation conducted has determined that the person in the requested State is clearly not the person named in the warrant; or

(c) The fact that execution of the request in its current form would require the requested State to breach a pre-existing treaty obligation undertaken with respect to another State. 
'unequivocal terms' of the obligation to arrest President Bashir and surrender him to the ICC. ${ }^{168}$ On 13 June 2015 the Pre-Trial Chamber II issued a decision following the Prosecutor's request for an order further clarifying that the Republic of South Africa is under the obligation to immediately arrest and surrender President Bashir. According to this decision:

it is unnecessary to further clarify that the Republic of South Africa is under the duty under the Rome Statute to immediately arrest Omar Al-Bashir and surrender him to the Court, as the existence of this duty is already clear and needs not be further reiterated..$^{169}$

As such there existed a clearly articulated legal basis and clear legal obligation for South Africa, as a party to the ICC, to arrest President Bashir in compliance with its obligations under the ICC Statute.

\section{South Africa's Obligations Based on its UN Membership}

Additionally, with respect to the Darfur situation it should be noted that South Africa's obligations come not only from its status as a State Party to the ICC Statute but also by virtue of its UN Membership. To recall, in the case of Darfur, the jurisdiction of the ICC was enacted through Security Council Resolution 1593, adopted on 31 March 2005. ${ }^{170}$ Resolution 1593 was the decision of the Security Council to refer to the ICC 'the situation in Darfur since 1 July 2002'. ${ }^{171}$ As Gillett correctly observes, with this resolution '[t]he United Nations thereby accepted the ICC's jurisdiction with respect to that situation, which encompasses the arrest warrants and proceedings against Bashir for genocide'. ${ }^{172}$ When passing this resolution, the Security Council was acting under its ch VIII powers concerning international peace and security. Pursuant to art 25 of the Charter of the United Nations, decisions of the Security Council concerning international peace and security are binding on all UN Members. Therefore, the referral of the Darfur situation to the ICC by Resolution 1593 'constitutes a collective acceptance on the part of UN Member States of the ICC's jurisdiction over the Darfur situation

168 PTC II Decision of 13 June 2015 (International Criminal Court, Pre-Trial Chamber II, ICC-02/0501/09-242, 13 June 2015) [8].

169 Ibid [10].

170 SC Res 1593, UN SCOR, 5158 ${ }^{\text {th }} \mathrm{mtg}$, UN Doc S/RES/1593 (31 March 2005).

171 Ibid [1]. On the question of the referral of the Darfur situation to the ICC see, eg, Dapo Akande, 'The Legal Nature of Security Council Referrals to the ICC and its Impact on Al Bashir's Immunities' (2009) 7 Journal of International Criminal Justice 333, 341 (noting that 'the referral of a situation to the ICC is a decision to confer jurisdiction on the Court (in circumstances where such jurisdiction may otherwise not exist)'); Paola Gaeta, 'Darfur Question: What are the Obligations of Contracting Parties to the Genocide Convention to Implement Arrest Warrants for Genocide Issues by the ICC, and of African Union State Parties to Implement ICC Arrest Warrants Generally?' on the International Criminal Court Forum (January-May 2011) <http://uclalawforum.com/darfur\#Gaeta>; Paola Gaeta, 'Does President Al Bashir Enjoy Immunity from Arrest?' (2009) 7 Journal of International Criminal Justice 315, 328-9.

172 Matthew Gillett, 'The Call of Justice: Obligations under the Genocide Convention to Cooperate with the International Criminal Court' (2012) 23 Criminal Law Forum 63, 76. 
... No UN Member State is able to deny that the ICC has jurisdiction over the Darfur situation'. ${ }^{173}$

UN Members are further required to accept the UN Security Council's decision to refer the Darfur situation to the ICC by virtue of art 103 of the Charter of the United Nations. Article 103 provides that obligations under the Charter of the United Nations prevail over obligations under other international instruments: 'In the event of a conflict between the obligations of the Members of the United Nations under the present Charter and their obligations under any other international agreement, their obligations under the present Charter shall prevail'. ${ }^{174}$ In the case at hand, this would mean that Sudan's denial of ICC's jurisdiction and South Africa's reliance on the AU's decision not to cooperate with the ICC are in dissonance with Resolution 1593 and in breach of relevant Charter of the United Nations provisions.

In terms of obligations that arise under Resolution 1593, the Security Council first explicitly made reference to the government of Sudan — a non-party to the ICC Statute - and all other parties to the conflict in Darfur. By using mandatory language in para 2 of Resolution 1593, the Security Council specified that these States 'shall cooperate fully with and provide any necessary assistance to the Court and the Prosecutor'. ${ }^{175}$ The second part of this paragraph addresses all other states. Here, by using softer language, and 'while recognizing that States not party to the Rome Statute have no obligation under the Statute', the Security Council 'urges all States and concerned regional and other international organizations to cooperate fully'. ${ }^{176}$ Based on this part of para 2, UN members which are also parties to the ICC Statute are under an obligation to cooperate fully with the ICC, but UN members 'and concerned regional and other international organizations' not party to the ICC Statute (except Sudan and 'all other parties to the conflict in Darfur') are not under such an obligation - they are merely being 'urged' to cooperate fully. ${ }^{177}$ With this 'gradation' the Security Council created 'a bifurcated standard" ${ }^{178}$ which has resulted in an ambiguous acceptance of the ICC's jurisdiction by states non-parties to the ICC Statute (except States Parties to the Darfur conflict, including Sudan). ${ }^{179}$

Notwithstanding the vagueness in para 2 of Resolution 1593 relating to the issue of obligations pertaining to states that are not party to the ICC Statute, Sudan,

173 Ibid

174 Charter of the United Nations art 103.

175 Resolution 1593, UN Doc S/RES/1325, para 2 (emphasis added).

176 Ibid (emphasis added).

177 Gillett, above n 172, 85 (observing that 'states not party to the Rome Statute are merely urged to cooperate but are recognized to have no obligations under the Rome Statute'). See also Nerina Boschiero, 'The ICC Judicial Finding on Non-Cooperation against the DRC and No Immunity for Al-Bashir Based on UNSC Resolution 1593' (2015) 13 Journal of International Criminal Justice 625, 645 (noting that the Security Council's use of the term 'urges' is to be interpreted as a non-binding determination).

178 Gillett, above $\mathrm{n} 172,85$.

179 Resolution 1593 needs to be distinguished from SC Res 827, UN SCOR, $48^{\text {th }}$ sess, $3217^{\text {th }} \mathrm{mtg}$, UN Doc S/RES/827 (25 May 1993) para 4 ('Resolution 827'). Whereas the latter requires that 'all States shall cooperate fully with the International Tribunal and its organs', the former uses more cautious wording vis-à-vis the referral of the Darfur situation to the ICC. 
being a non-party state, is under an obligation to cooperate fully with the ICC by virtue of its UN membership. As noted, this has been unequivocally spelt out by the first part of para 2 of Resolution 1593. Sudan's obligation to cooperate with the ICC pursuant to Resolution 1593 is similar to Serbia's obligation to cooperate with the ICTY. Even though it did not vote for the establishment of the ICTY, Serbia's membership in the UN was deemed its acceptance of the ICTY's jurisdiction. ${ }^{180}$

As far as South Africa is concerned, by being a member of the UN which is also party to the ICC Statute, South Africa is clearly in the category of states which are, pursuant to the second part of para 2 of Resolution 1593, obliged to 'cooperate fully' with the ICC. South Africa has failed to comply with the terms of Resolution 1593 in failing to arrest President Bashir. ${ }^{181}$

\section{South Africa's Obligations under the Genocide Convention}

The warrant for President Bashir's arrest of 12 July 2010 was issued on the basis of there being 'reasonable grounds to believe that Omar Al Bashir is criminally responsible' for:

i. Genocide by killing, within the meaning of Article 6(a) of the Statute;

ii. Genocide by causing serious bodily or mental harm, within the meaning of Article 6(b) of the Statute; and

iii. Genocide by deliberately inflicting conditions of life calculated to bring about physical destruction, within the meaning of Article 6(c) of the Statute. ${ }^{182}$

Since the adoption in 1948 of the Genocide Convention the prohibition on the crime of genocide has become clearly articulated as customary international law, ${ }^{183}$ a crime to which obligations erga omnes ${ }^{184}$ and jus cogens attach. ${ }^{185}$ South Africa acceded to the Genocide Convention on 10 December 1998; Sudan acceded

180 Application of the Convention on the Prevention and Punishment of the Crime of Genocide (Bosnia and Herzegovina $v$ Serbia and Montenegro) (Judgement) [2007] ICJ Rep 43, 227-8 [444]-[447] ('Bosnian Genocide').

181 Gillett, above n 172, 75-81; Boschiero, 'The ICC Judicial Finding on Non-Cooperation against the DRC', above n 177, 645.

182 Second Arrest Warrant (International Criminal Court, Pre-Trial Chamber I, Case No ICC-02/0501/09-1, 12 July 2010) 8.

183 John Quigley, The Genocide Convention: An International Law Analysis (Ashgate, 2006) ch 11; Cassese, International Criminal Law, above n 140, 444.

184 Obligations erga omnes are those obligations which, due to their nature as the most important of rights, concern all states. The Barcelona Traction case in 1970 established the notion of 'obligations towards the international community as a whole' which were, by 'their very nature ... the concern of all States' and which, '[i]n view of the importance of the rights involved, all States can be held to have a legal interest in their protection': Barcelona Traction, Light and Power Company, Limited (Belgium v Spain) (Second Phase Judgment) [1970] ICJ Rep 3, 32 [33] ('Barcelona Traction').

185 A peremptory norm of general international law (jus cogens) is a norm accepted and recognised by the international community of states as a whole as a norm from which no derogation is permitted and which can be modified only by a subsequent norm of general international law having the same character: see Vienna Convention art 53. See also Cassese, International Criminal Law, above n 140, $434-45$. 
to the convention five years later, with no reservations. ${ }^{186}$ Therefore, Sudan cannot claim that it is being subjected to a legal instrument by which it is not bound. ${ }^{187}$

Article 1 of the Genocide Convention provides that 'Contracting Parties confirm that genocide, whether committed in time of peace or in time of war, is a crime under international law which they undertake to prevent and to punish'. This is consistent with the ICJ's holding in the Bosnian Genocide case that all States Parties to the Genocide Convention have an obligation in relation to the punishment of those who have committed genocide. ${ }^{188}$ Pursuant to art 4 of the Genocide Convention, '[p] ersons committing genocide or any of the other acts enumerated in Article 3 shall be punished, whether they are constitutionally responsible rulers, public officials or private individuals'. Therefore, no one, including heads of states, is exempt from accountability for these acts. Article 6 of the Genocide Convention makes clear that this applies to both domestic and international level. Article 6 calls for the trial of persons who are accused of acts prohibited by the Convention, namely:

Persons charged with genocide or any of the other acts enumerated in Article III shall be tried by a competent tribunal of the state in the territory of which the act was committed, or by such international penal tribunal as may have jurisdiction with respect to those Contracting Parties which shall have accepted its jurisdiction. ${ }^{189}$

In the Bosnian Genocide case, the ICJ explicated that art 6 of the Genocide Convention obliges states to exercise jurisdiction on the basis of territorial jurisdiction or surrender the suspect to an international penal tribunal 'failing prosecution of them in the parties' own courts.'. ${ }^{\text {190 }}$

This provision (of art 6) is binding on both South Africa and Sudan as States Parties to the Genocide Convention and engages their obligation. These two states have accepted jurisdiction of an 'international penal tribunal' referred to in art 6 of the Genocide Convention, which is the ICC in the instant case: the former by becoming de jure party to its Statute (ie, by ratifying the ICC Statute) and the latter by becoming 'a de facto State Party to the Rome Statute by virtue of Resolution 1593'. ${ }^{191}$ Accordingly, both States are obligated to cooperate with this international penal tribunal. The obligation to cooperate with the international penal tribunal, as implicitly envisaged by art 6 of the Genocide Convention, ${ }^{192}$ is clarified by the ICJ in the Bosnian Genocide case:

186 For the current status of the Genocide Convention, see Convention on the Prevention and Punishment of the Crime of Genocide, United Nations Treaty Collection <https://treaties.un.org/Pages/ ViewDetails.aspx?src=IND\&mtdsg_no $=I V-1 \&$ chapter $=4 \&$ clang $=$ en $>$.

187 Goran Sluiter, 'Using the Genocide Convention to Strengthen Cooperation with the ICC in the $\mathrm{Al}$ Bashir Case' (2010) 8 Journal of International Criminal Justice 365, 379.

188 Bosnian Genocide [2007] ICJ Rep 43, 226-9 [439]-[450].

189 Genocide Convention art 6.

190 Bosnian Genocide [2007] ICJ Rep 43, 226-7 [442]-[443].

191 Akande, 'The Legal Nature of Security Council Referrals to the ICC', above n 171, 340-2.

192 See generally Gillett, above n 172. 
it is certain that once such a court has been established, Article VI obliges the Contracting Parties 'which shall have accepted its jurisdiction' to cooperate with it, which implies that they will arrest persons accused of genocide who are in their territory - even if the crime of which they are accused was committed outside it — and, failing prosecution of them in the parties' own courts, that they will hand them over for trial by the competent international tribunal. ${ }^{193}$

Given that the international community lacks an international police force, states have the obligation to apprehend persons charged with genocide. Thus, as the Convention itself spells it out, 'international cooperation is required'. ${ }^{194}$ To think differently would be inconsistent with the object and purpose of the Genocide Convention, that is, the prevention and punishment of genocide. ${ }^{195}$ In its Advisory Opinion on Reservations to the Genocide Convention, the ICJ noted that one of the consequences of genocide being a crime under international law is the universal character both of the condemnation of genocide and of the cooperation required "in order to liberate mankind from such an odious scourge"" ${ }_{196}$

Therefore, there is a very clear obligation arising from both treaty and customary law, and the existence of evidence of the crime of genocide, to arrest President Bashir and transfer him to the ICC. This argument has previously been noted in relation to the failures of other States to arrest President Bashir in the past. ${ }^{197}$ What sets the South African situation apart, however, is the depth of the domestic judicial response to the government's failure to act upon the ICC's arrest warrants and the subsequent increase of general interest in the issue of head of state immunity echoed worldwide.

\section{Arguments against Arrest}

A number of arguments have been made in support of the proposition that President Bashir should not have been arrested during his visit to South Africa. These arguments essentially reflect two concerns - one is legal and the other is geo-political.

\section{Legal Arguments}

The arguments against arrest of President Bashir mainly revolve around the head of state immunity and the validity of the AU position on head of state immunity. As discussed, President Bashir was in South Africa to attend the $25^{\text {th }}$ AU Summit. Arguably the South African government sought to grant immunity to all attending

193 Bosnian Genocide [2007] ICJ Rep 43, 226 [443].

194 Genocide Convention Preamble.

195 Genocide Convention art 1.

196 Reservations to the Convention on the Prevention and Punishment of the Crime of Genocide (Advisory Opinion) ICJ Reports [1951] ICJ 15, 7 ('Reservations to the Genocide Convention Opinion').

197 Henok G Gabisa and Matt Davis, International Criminal Justice and the President Omar AlBashir of Sudan: A Rejuvenated Call on the International Community to Effectuate the Arrest Warrant Advocates for Human Dignity (18 October 2013) Advocate Dignity <http://advocatedignity. org/?p=18\#sthash.7eluQdQp.dpuf>. 
the Summit. ${ }^{198}$ It was contended that the ICC requests to arrest President Bashir were preempted by the obligation to respect President Bashir's immunities as head of a member state of the AU.

However, the argument that President Bashir could be granted immunity for the commission of crimes falling within the ICC's jurisdiction is flawed. To say again, pursuant to art 27(1), the ICC Statute applies to all individuals irrespective of their official capacity and specifically includes heads of state:

This statute shall apply equally to all persons without any distinction based on official capacity. In particular, official capacity as a head of state or government, a member of a government or parliament, an elected representative or a government official shall in no case exempt a person from criminal responsibility under this statute, nor shall it, in and of itself, constitute a ground for reduction of sentence. ${ }^{199}$

Nevertheless, basing its arguments on the 2009 AU's decision not to cooperate with the ICC, pursuant to art 98 of the ICC Statute, until the UN Security Council has considered the request by the $\mathrm{AU}$ for a deferral of its decision to refer the matter to the ICC, and despite the subsequent practice of the Security Council (which included the adoption of Resolution 1593), the South African government decided that it was not obliged to arrest President Bashir. Under this argument, President Bashir is shielded by art 98(1) which refers to head of state immunity, guaranteed by customary international law, which is an absolute immunity and which can only be lifted by Sudan's waiver.

According to the South African government, South Africa's refusal to arrest President Bashir is further strengthened by art 98(2) which refers to other international agreements, which is in this case again the 2009 AU decision not to cooperate with the ICC, pursuant to art 98 of the ICC Statute. However, it is difficult (impossible) to qualify this decision as a 'preexisting treaty obligation' incumbent upon South Africa. ${ }^{200}$

The South African government has stressed that there is the tension between arts 27(2) and 98 of the ICC Statute and that the ICC needs to provide clear guidelines in order to assist States Parties with fulfilling their obligation to cooperate with

198 Southern Africa Litigation Centre [2015] 5 SA 1, 9. See also Gilbert M Khadiagala, 'Why a Great Deal Hangs on Al-Bashir's Fate in South Africa', The Conversation (online), 15 June $2015<\mathrm{https}$ // theconversation.com/why-a-great-deal-hangs-on-al-bashirs-fate-in-south-africa-43229>; Politics Web, Statement Issued by the African National Congress (14 June 2015) <www.politicsweb.co.za/ politics/goct-gazetted-albashirs-immunity-anc>.

199 ICC Statute art 27(1).

200 Nerina Boschiero, 'South Africa and Al-Bashir's Escape from the ICC' on OUP Blog (13 July 2005) $<$ http://blog.oup.com/2015/07/south-africa-al-bashirs-escape-icc $>$. 
the ICC vis-à-vis arrest warrants. ${ }^{201}$ In the government's view arts 27 and 98 seem to fully contradict one another: while art 27 removes immunity of heads of state, art 98 appears to require the ICC to respect immunity when requesting state cooperation.

The question of the tension between art 27 and 98 has also caught scholarly attention. For example, Akande argues that the only way to give meaningful effect to both provisions is to interpret art 98 as requiring the ICC and national authorities to respect immunities accruing to non-parties and that art 27 is to be taken as removing immunities accruing to ICC Parties. ${ }^{202}$ Blommestijn and Ryngaert distinguish between immunity from prosecution and immunity from arrest. The former is governed by art 27(2), which provides that '[i]mmunities or special procedural rules which may attach to the official capacity of a person, whether under national or international law, shall not bar the Court from exercising its jurisdiction over such a person'. ${ }^{203}$ The latter is dealt with by art 98, which concerns the traditional types of immunity recognised under international law and establishes the conditions under which the ICC may proceed with a request for surrender or assistance.

However, these two scholars explain that these are different types of immunity as 'they address two completely separate stages of the ICC's proceedings' ${ }^{204}$ They argue that art 98(1) precludes national authorities of State Parties from acting upon the warrant under customary international law. They contend that only if President Bashir's immunity was waived, a subsequent UN Security Council resolution (to remove art 98's requirement to secure the cooperation of the third state) to be adopted, or President Bashir to be removed from office, would states

201 See, eg, Barnes, above n 56, 1616; Assembly of States Parties, List of Supplementary Items Requested for Inclusion in the Agenda of the $14^{\text {th }}$ Session of the Assembly, ICC-ASP/14/35 (27 October 2015) (which included a request by South Africa for the inclusion of a supplementary agenda item 'Application and Implementation of Article 97 and Article 98 of the Rome Statute': at [1(a)]). Cf Human Rights Watch, 'Human Rights Watch Briefing Note for the Fourteenth Session of the International Criminal Court Assembly of States Parties' (Briefing Note, Human Rights Watch, 9 November 2015) <https:// www.hrw.org/news/2015/11/09/human-rights-watch-briefing-note-fourteenth-session-internationalcriminal-court $>$, which strongly opposes inclusion of this item on the agenda of the ASP:

ICC States Parties should: avoid discussions during the ASP session that are aimed or could be perceived as aiming at undermining the independence of the court's judges with regard to pending decisions; and emphasize in general debate and other appropriate statements during the Assembly session, including in response to any effort to politicize pending cases, the independence of the ICC and its prosecutor and commit to protecting the court from political interference.

202 See, eg, Dapo Akande, 'International Law Immunities and the International Criminal Court' (2004) 98(3) American Journal of International Law 403. It should be noted that Akande does address the question of non-parties subject to a Security Council resolution under art 13(b) of the ICC Statute. See also Akande, 'The Legal Nature of Security Council Referrals to the ICC', above n 171; Akande, 'The Effect of Security Council Resolutions and Domestic Proceedings on State Obligations to Cooperate with the ICC', above n 36.

203 For a discussion about the meaning of art 27, see, eg, Von Michiel Blommestijn and Cedric Ryngaert, 'Exploring the Obligations for States to Act upon the ICC's Arrest Warrant for Omar Al-Bashir: A Legal Conflict between the Duty to Arrest and the Customary Status of Head of State Immunity' (2010) 6 Journal for International Doctrine in Criminal Law 428.

204 Ibid 439. 
be allowed to arrest and surrender President Bashir to the ICC. ${ }^{205}$ Under this argument, the Pre-Trial Chamber, when making its request for state cooperation, acted in violation of art 98(1) and thus acted ultra vires. ${ }^{206}$

While art 98 may appear to be causing confusion and may benefit from more clarity, it did not preclude South Africa from complying with the ICC's request to arrest President Bashir. In the DRC Decision, the ICC Pre-Trial Chamber II settled the same matter. It is worth recalling that Resolution 1593 adopted by the UN Security Council, acting under ch VIII of the Charter of the United Nations, had already conferred jurisdiction over the Darfur situation on the ICC and recognised that immunity of a sitting head of state does not apply in this case. ${ }^{207}$ In its second paragraph the Resolution also asked states to cooperate with the ICC. Furthermore, all states have to comply with Security Council's decisions. UN member states' obligations under the Charter of the United Nations take precedence over obligations under any other states' agreements. ${ }^{208}$ It follows that South Africa's decision not to arrest President Bashir was in defiance of its obligations emanating from its ICC and UN membership. In parallel, by refusing to cooperate with the ICC, South Africa was also in dissonance with its obligations under the Genocide Convention.

\section{Geo-Political Arguments}

The geo-political arguments pertain generally to the African concerns, not only with the actions of the ICC itself, ${ }^{209}$ but with the implications for an African nation who complies with the ICC's arrest warrant in defiance of the AU position on the warrant.

The attitude of the AU towards the ICC became hostile in 2008 upon the indictment by the ICC of President Bashir. ${ }^{210}$ The AU position is that the ICC Statute does not remove immunity granted by international law to officials of states not party to this Statute. ${ }^{211}$ In 2009, the AU Peace and Security Council issued a Communiqué in which it 'express[ed] deep concern over the decision ... to issue an arrest warrant against ... Al-Bashir ... at a critical juncture in the

205 Ibid. See also Max du Plessis, 'South Africa's Implementation of the ICC Statute: An African Example' (2007) 5 Journal of International Criminal Justice 460.

206 Blommestijn and Ryngaert, above n 203, 440. See also Barnes, above n 56, 1616.

207 See Resolution 1593 para 1. See also Gillett, above n 172, 93.

208 Charter of the United Nations arts 25, 103.

209 See, eg, Tim Murithi, 'Between Political Justice and Judicial Politics: Charting a Way Forward for the African Union and the International Criminal Court' in G Werle et al (eds), Africa and the International Criminal Court (TM Asser Press, 2014) 179, 181.

210 Ibid 180.

211 African Union Assembly, Decision on the Progress Report of the Commission on the Implementation of the Assembly Decision on the International Criminal Court, Assembly/AU/Dec.334 (XVI) (30 January 2012) [6]. See also African Union Assembly, Decision on Africa's Relationship with the International Criminal Court, Ext/Assembly/AU/Dec.1 (1 October 2013) [9]-[10(i)]; African Union, 'AU Commission Chairperson and Senegalese Justice Minister, also President of Assembly of State Parties of Rome Statute Discuss Hissène Habré Case and Africa-ICC Relations' (Press Release, 190/2015, 18 August 2015). 
process to promote lasting peace, reconciliation and democratic governance in the Sudan. ${ }^{212}$

The AU adopted the view that the ICC's decision 'may lead to further suffering for the people of the Sudan' 213 and criticised the UN Security Council for failing to comply with the request by the AU to apply art 16 of the ICC Statute which would have deferred the prosecution. In July 2010 the AU renewed its call for members not to arrest President Bashir pursuant to the ICC arrest warrant. ${ }^{214}$ This AU position was also reiterated in January 2012 at the $18^{\text {th }}$ Ordinary Session of the Assembly of African Union Heads of State and Government. ${ }^{215}$ The AU decision highlighted the need for African States to continue to push the UN Security Council to place the matter of the ICC Statute art 16 deferral provision in relation to Sudan. ${ }^{216}$

On the events of June 2015 in letting President Bashir depart South Africa, the South African government is reported as having tweeted 'South Africa had "to balance its obligations to the ICC with its obligations to the AU and individual States". ${ }^{217}$ African National Congress Secretary General Gwede Mantashe is also noted as having said arresting President Bashir would have led to war with Sudan. ${ }^{218}$

One might argue that there is no legal basis not to arrest President Bashir and a completely clear legal basis to do so. Nevertheless, given the repeated failures of a number of states to arrest President Bashir in compliance with international obligations, the strong position of the $\mathrm{AU}$ on this issue and the concerns of African States about instability in the region, President Bashir looks set to continue to avoid arrest in Africa in the foreseeable future. This creates multiple consequences not only for the states most immediately concerned, but also for the ICC both internally and externally.

212 African Union Assembly, Communique of the 175 Security Council, PSC/PR/Comm. (CLXXV) (5 March 2009) [2] <http://www.peaceau.org/uploads/ iccarrestwarranteng.pdf>.

213 Ibid [4].

214 Elise Keppler 'Managing Setbacks for the International Criminal Court in Africa' (2012) Journal of African Law 1.

215 African Union Assembly, Decision on the Progress Report of the Commission on the Implementation of the Assembly Decision on the International Criminal Court, Assembly/AU/Dec.334 (XVI) (30 January 2012) [7]-[8].

216 Ibid [3].

217 'South Africa May Leave ICC over Bashir Arrest Row', BBC News Africa (online), 25 June 2015 $<$ http://www.bbc.com/news/world-africa-33269126>.

218 Sarah Evans, 'Why State Says Bid to Arrest al-Bashir Was a Mistake', Mail \& Guardian (online), 15 July $2015<$ http://mg.co.za/article/2015-07-15-why-state-believes-bid-to-arrest-bashir-was-amistake>. 


\section{Consequences of the June 2015 South Africa Events}

\section{Pursuant to the ICC Statute}

The key provision in respect of failures by states to comply with their obligations to the ICC is art $87(7)$ of the ICC Statute. Article $87(7)$ provides:

Where a State Party fails to comply with a request to cooperate by the Court contrary to the provisions of this statute, thereby preventing the Court from exercising its functions and powers under this statute, the Court may make a finding to that effect and refer the matter to the Assembly of States Parties or, where the Security Council referred the matter to the Court, to the Security Council.

As it has been seen with the earlier failures of other African states to arrest President Bashir, the response of the ICC is to find the state having failed to comply with its obligations under the ICC Statute and, to refer its decision to the President of the ICC for transmission to the Security Council and the Assembly of States Parties to the ICC. ${ }^{219}$ Shortly after the AU summit in South Africa, on 24-25 June 2015, a resumed session of Assembly of States Parties $13^{\text {th }}$ session was held in The Hague. The issue of non-compliance was not discussed there but it was the supplementary agenda item (proposed by South Africa, however) for the $14^{\text {th }}$ session of the Assembly of States Parties, which was held in The Hague from 18-26 November 2015.

Because the situation in Darfur was referred to the ICC by the Security Council, the referral to the Security Council has particular significance. Article 17(3) of the Negotiated Relationship Agreement between the International Criminal Court and the United Nations applies. ${ }^{20}$ This means that where a state fails to cooperate with the Court, the Court shall inform the Security Council. The Security Council is to inform the Court of its action it takes in response, if any. On 26 June 2015, the ICC's Pre-Trial Chamber communicated to the Security Council the $10^{\text {th }}$ finding of Sudan's non-compliance in not arresting and rendering President Bashir to the Court. ${ }^{221}$

It is also worth noting that in her briefing to the Security Council of 12 December 2014, the ICC Prosecutor announced that the ICC was 'suspending investigations in Darfur because none of the Sudanese individuals indicted by the Court had been brought to justice and that the Council had failed to act decisively'. ${ }^{22}$ In

219 See, eg, Prosecutorv Omar Hassan Ahmad Al Bashir (Decision on the Non-Compliance of the Republic of Chad with the Cooperation Requests Issued by the Court Regarding the Arrest and Surrender of Omar Hassan Ahmad Al-Bashir) (International Criminal Court, Pre Trial Chamber II, ICC-02/05-01/09, 26 March 2013) 11; DRC Decision (International Criminal Court, Pre-Trial Chamber II, Case No ICC-02/05-01/09-1, 9 April 2014) 17.

220 Negotiated Relationship Agreement between the International Criminal Court and the United Nations, (entered into force 4 October 2004) <http://www.icc-cpi.int/NR/rdonlyres/916FC6A27846-4177-A5EA-5AA9B6D1E96C/0/ICCASP3Res1_English.pdf>.

221 United Nations, 'International Criminal Court Prosecutor Tells Security Council Her Resolve to Bring Impartial Justice to People of Darfur Remains Unshaken' (Meetings Coverage, SC/11954, 29 June 2015) <http://www.un.org/press/en/2015/sc11954.doc.htm>.

222 Ibid [2]. 
her briefing to the Council on 29 June 2015, the ICC Prosecutor reminded the Security Council that those individuals, including President Bashir, were still wanted by the Court.

On 4 September 2015, the ICC judges requested submissions from South Africa to determine whether to issue a finding of non-cooperation with respect to the President Bashir visit. ${ }^{223}$ Again, no Security Council response was transmitted. Given that Sudan is not a party to the ICC Statute the Security Council needed to take more active role in terms of enforcing the arrest warrants against President Bashir. In her semi-annual briefing to the Council on 9 June 2016, the ICC Prosecutor reminded the Council of its duty to act and of its failure to do so despite her 'countless appeals'. 224

\section{Domestically in South Africa}

The events of June 2015 have also resulted in the airing of strong views on the ICC in South Africa. Mantashe is quoted as saying that South Africa should withdraw from the ICC. ${ }^{225}$ In her speech to the Assembly of States Parties to the ICC Statute on 18 November 2015, Maite Nkoana-Mashabane, South African Minister of International Relations and Cooperation, made no such threat explicitly. However, some cautioned that her concluding remark that the ICC is 'at the cross-roads' might be taken as warning. ${ }^{226}$ The South African National Congress is quoted as saying it wants a review to be undertaken of the 'statutes' of the ICC to ensure a 'fair and independent court'. ${ }^{227}$ The opposition Democratic Alliance on the other hand is reported as noting that ' $[t]$ he Zuma government has committed a crime of allowing a wanted man to evade the law'.228

223 Prosecutor v Omar Hassan Ahmad Al Bashir (Order Requesting Submissions from the Republic of South Africa for the Purposes of Proceedings under Article 87(7) of the Rome Statute) (International Criminal Court, Pre-Trial Chamber, Case No ICC 02/05-01/09, 4 September 2015). South Africa requested and was granted an extension to file its submission while litigation in South Africa's domestic courts on the visit was pending: see Prosecutorv Omar Hassan Ahmad Al Bashir (Decision on the Request of the Republic of South Africa for an Extension of the Time Limit for Submitting their Views for the Purposes of Proceedings under Article 87(7) of the Rome Statute) (International Criminal Court, Pre-Trial Chamber II, Case No ICC 02/05-01/09, 15 October 2015).

224 United Nations, 'International Criminal Court's Chief Prosecutor, Briefing Security Council, Criticises Failure to Address Sudan's "Persistent Failure” on Darfur' (Meetings Coverage, SC/12393, 9 June 2016) <http://www.un.org/press/en/2016/sc12393.doc.htm>.

225 'Mantashe: ICC Is Dangerous, SA Should Withdraw', News 24 (online), 22 June 2015, <http://www. news24.com/SouthAfrica/News/Mantashe-ICC-is-dangerous-SA-should-withdraw-20150622>; Evans, above n 218; 'SA May, as a Last Resort, Withdraw from ICC, Says Radebe', Business Day Live (online), 25 June $2015<$ http://www.bdlive.co.za/national/2015/06/25/sa-may-as-a-last-resortwithdraw-from-icc-says-radebe>.

226 Agence France-Presse, 'African Union Blasts ICC', ENews Channel Africa (online), 19 November $2015<\mathrm{https}: / /$ www.enca.com/africa/icc-crossroads-says-sa>.

227 Owen Bowcott, 'Sudan President Omar al-Bashir Leaves South Africa as Court Considers Arrest', The Guardian (online), 16 June $2015<\mathrm{http}$ ://www.theguardian.com/world/2015/jun/15/south-africato-fight-omar-al-bashirs-arrest-warrant-sudan>.

228 'Government Could Face Criminal Charges Over al-Bashir Fiasco', Mail \& Guardian (online), 24 Jun $2015<$ http://mg.co.za/article/2015-06-24-sd $>$. 
Murithi, writing before President Bashir visited South Africa, observed that South Africa's position regarding the ICC has been of particular interest in recent times. Murithi noted the appointment of South African's Nkosazana Dlamini-Zuma as Chairperson of the AU Commission in January 2012 and that Dlamini-Zuma was more likely to be an advocate for the AU position than one for the ICC's agenda on the African continent. ${ }^{229}$ Dlamini-Zuma is the incumbent Chairperson whose term is four years. ${ }^{230}$

It remains to be seen what further developments will be in the African context following the election of the next AU Chairperson. As far as South Africa is concerned, on 15 March 2016, South Africa's Supreme Court of Appeal upheld the 2015 decision of South Africa's High Court that South African government acted unlawfully in allowing President Bashir to escape South Africa in June 2015. The South African government was studying the ruling and had to decide whether it would challenge it at the Constitutional Court, the highest court in South Africa. If the government did appeal the Supreme Court of Appeal decision that could even further reinforce the High Court's condemnation of its action. At the same time, South Africa was expected to explain to the ICC why it failed to act upon the ICC's arrest warrants. The ICC allowed South Africa to postpone providing such an explanation until the government's appeal process was complete. With the decision of the Supreme Court of Appeal, South Africa seemed to be closer to account for its disrespect for its obligations under international law pertaining to the Bashir case. As noted, the ICC could refer the matter to the UN Security Council, which has the power to impose punitive action. Simultaneously, the Supreme Court of Appeal's decision meant that anyone, including President Bashir, facing arrest warrants issued by the ICC would be arrested if they came to South Africa. Ultimately, this equaled to the confirmation of the commitment to human rights both at a national and an international level.

However, the Supreme Court of Appeal's decision could also further deepen the divergence between South Africa's government and judiciary, with serious consequences. It was feared that one such consequence could be South Africa's withdrawal from the ICC. This proved to be true when in October 2016 the South African government did the seemingly unthinkable: it confirmed that it was withdrawing from the ICC, claiming that being part of the ICC was 'incompatible' with its efforts to mediate peace in Africa. ${ }^{231}$ This was an attack not only on the

229 Murithi, above n 209, 185.

230 Chad's Foreign Minister, Moussa Faki Mahamat was elected as a new Chairperson of the AU Commission: 'Chad Foreign Minister Moussa Faki Mahamat to Head African Union', The Guardian (online), 31 January $2017<$ https://www.theguardian.com/global-development/2017/jan/30/chadforeign-minister-moussa-faki-mahamat-african-union-head $>$.

231 See, eg, Azad Essa, 'South Africa's Withdrawal from the International Criminal Court Reeks of Hypocrisy' The Washington Post (online), 26 October $2016<\mathrm{https}$ //www.washingtonpost.com/news/ global-opinions/wp/2016/10/26/south-africas-withdrawal-from-the-international-criminal-courtreeks-of-hypocrisy/?utm_term $=.50 \mathrm{c} 3264 \mathrm{fcbe} 0>$. 
ICC but also on its own law and judiciary. ${ }^{232}$ South Africa's withdrawal came only days after Burundi signaled its intention to leave the ICC, and was also followed by Gambia's similar announcement, accusing the ICC of the 'persecution and humiliation of people of colour, especially Africans', ${ }^{233}$ and the argument made by some other African States that 'there's a need for the whole of Africa to withdraw from the ICC' ${ }^{234}$

\section{Globally for the ICC}

South Africa is now added to the list of states parties to the ICC Statute which have failed to arrest President Bashir - Malawi, the Democratic Republic of the Congo, Chad, Kenya and Djibouti. ${ }^{235}$ The failure clearly has implications for the ICC. Relations between the ICC and Africa are evidently strained. This was the case long before the non-arrest by South Africa. ${ }^{236}$ Recently the President of the Assembly of States Parties to the ICC Statute, Sidiki Kaba, met with Dr Nkosazana Dlamini-Zuma, Chairperson of the AU Commission. Mr Kaba was quoted as saying 'I am convinced that there is an urgent need to restore trust between the Court and African States Parties to the Rome Statute'. ${ }^{237}$

After the decision of the ICC in relation to the Democratic Republic of the Congo's failure to arrest President Bashir, Boschiero asked: 'Has the Court lost patience?'238 It has been remarked that it would seem that it has, and that the decision of the Court considering South Africa's failure to arrest President Bashir will be an interesting read to determine if there is anything further the ICC can do in the face of the AU's position that President Bashir should not be brought to The Hague.

232 Peter Fabricius, Breaking the Law for Bashir (17 March 2016) Institute for Security Studies $<$ https:// www.issafrica.org/iss-today/breaking-the-law-for-bashir>; Richard Goldstone, a former Justice of the Constitutional Court of South Africa, characterised South Africa's notice of withdrawal as 'unfortunate on legal, moral and political grounds', and Stephen J Rapp, a former United States ambassador at large for global criminal justice, viewed the decisions by Burundi and South Africa as 'a betrayal of the victims of atrocious crimes': see Sewell Chan and Marlise Simons, 'South Africa to Withdraw from International Criminal Court', The New York Times (online), 21 October $2016<\mathrm{http} / / /$ www.nytimes.com/2016/10/22/world/africa/south-africa-international-criminal-court.html $>$.

233 Agence France-Presse, 'Gambia is Latest African Nation to Quit International Criminal Court', The Guardian (online), 26 October $2016<\mathrm{https}$ //www.theguardian.com/world/2016/oct/26/gambiabecomes-latest-african-nation-to-quit-international-criminal-court>. See also Ed Cropley, 'ICC's Toughest Trial: Africa v "Infamous Caucasian Court", Reuters (online), 28 October $2016<\mathrm{http}$ :// af.reuters.com/article/topNews/idAFKCN12S1MQ?sp=true>.

234 See, eg, Cropley, above n 233.

235 See, eg, Southern Africa Litigation Centre [2015] 5 SA 1; Barnes, above n 56.

236 See, eg, Murithi, above n 209; Keppler, above n 214.

237 International Criminal Court, 'The President of the Assembly of States Parties Meets with the Chairperson of the African Union Commission and with the Bureau of the Committee of Representatives' (Press Release, ICC-ASP-20150814-PR1138, 14 August 2015) <https://www.icccpi.int/Pages/item.aspx?name=pr1138>. See also Agence France-Presse, 'Gambia is Latest African Nation to Quit International Criminal Court', above $\mathrm{n} 233$.

238 Boschiero, 'The ICC Judicial Finding on Non-Cooperation against the DRC', above n 177, 626. 
African states were heavily involved in bringing about the ICC and the ICC Statute is well ratified in the region. ${ }^{239}$ African support is important for the Court. Murithi observes:

It is an understatement to note that the relationship between the African Union and the [ICC] has commenced badly. Indeed, one could not imagine a worse start. Both organizations share a convergence of mandates to address impunity and to ensure accountability for violations, atrocities and harm done in the past. The organizations diverge in that the African Union is a political organization and the International Criminal Court is an international judicial organization ... On paper it would appear that the two approaches may never converge. ${ }^{240}$

The AU has noted an intention to take the issue to the ICJ for an Advisory Opinion on the issue of head of state immunity. ${ }^{241}$ This may well be a positive development in so far as it resolves the outstanding legal issue and paves the way for some convergence and therefore greater support by Africa for the institution going forward.

Equally, if another state had the political will, South Africa could be brought before the ICJ for its failure to cooperate with the ICC.

\section{CONCLUSION}

The role of both functional and personal immunities for state officials is still significant in the panoply of international law. This doctrine under international law is durable and is applicable in most domestic court proceedings where action is attempted against such officials. It is also equally clear, though, that when it comes to crimes of international law attracting universal jurisdiction the domestic courts much more cautiously assess functional immunity and have been prepared to construe more narrowly what an official act is. In the context of international tribunals and courts exercising jurisdiction over similar classes of laws, the 'horizontal' sensitivities of competing sovereignties are not applicable. Moreover, after a slow start, both treaty and customary international law in the late $20^{\text {th }}$ and early $21^{\text {st }}$ centuries are resolute in ensuring that official status is irrelevant to the exercise of jurisdiction in the context of international criminal law. Such a trend parallels the general thrust of international law and its agency in realising greater protection to human rights and to make accountable those that egregiously violate fundamental standards of international behaviour.

States have to play their crucial roles in bringing to justice those responsible for violations of such standards. However, as the ICC's experience with South Africa's refusal to arrest President Bashir demonstrates, the interference of the political nuances into the legal fora curtails efforts to end impunity for incumbent heads

239 As of February 2017, out of 124 parties to the ICC Statute, 34 are African States: International Criminal Court, The States Parties to the Rome Statute <https://asp.icc-cpi.int/en_menus/asp/ states $\% 20$ parties/pages/the $\% 20$ states $\% 20$ parties $\% 20$ to $\% 20$ the $\% 20$ rome $\% 20$ statute.aspx $>$.

240 Murithi, above n 209, 187 (emphasis added).

241 Ibid 184. 
of state. Those nuances may create serious implications for future effectiveness of the ICC and may ultimately pose deep challenges for delivery of justice for victims of the most serious crimes, including genocide, which are of concern to the entire international community. 